OPEN ACCESS

Edited by:

Juan Armando Sanchez, University of Los Andes, Colombia

Reviewed by:

Ashley Alun Rowden,

National Institute of Water and Atmospheric Research (NIWA),

New Zealand

Les Watling,

University of Hawaii at Manoa, United States

Alan Williams,

Oceans and Atmosphere (CSIRO),

Australia

*Correspondence: Geoffrey G. Shester gshester@oceana.org

Specialty section:

This article was submitted to Deep-Sea Environments and Ecology, a section of the journal

Frontiers in Marine Science

Received: 10 January 2020 Accepted: 17 December 2020 Published: 28 January 2021

Citation:

Shester GG, Enticknap B, Mecum B, Blacow-Draeger A, Brock T and Murray S (2021) A

Win-Win for Deep-Sea Corals

and Fishing: Increasing Seafloor Protections While Restoring Fishing Opportunities Off the United States

West Coast.

Front. Mar. Sci. 7:525619. doi: 10.3389/fmars.2020.525619

\section{A Win-Win for Deep-Sea Corals and Fishing: Increasing Seafloor Protections While Restoring Fishing Opportunities Off the United States West Coast}

\author{
Geoffrey G. Shester ${ }^{1 *}$, Ben Enticknap ${ }^{2}$, Brianne Mecum ${ }^{3}$, Ashley Blacow-Draeger ${ }^{1}$, \\ Tara Brock ${ }^{2}$ and Susan Murray ${ }^{3}$
}

${ }^{1}$ Oceana, Inc., Monterey, CA, United States, ${ }^{2}$ Oceana, Inc., Portland, OR, United States, ${ }^{3}$ Oceana, Inc., Juneau, AK, United States

On January 1, 2020, the United States (U.S.) government implemented new regulations increasing total closed areas to bottom trawl fishing by $363,513 \mathrm{~km}^{2}$, including a net increase of $44,498 \mathrm{~km}^{2}$ in essential fish habitat conservation areas at fishable depths $(<1,280 \mathrm{~m})$ along the West Coast continental shelf and upper slope. At the same time, the government reopened certain bottom trawl fishing grounds originally established to rebuild overfished groundfish. In combination with previously existing conservation areas, the result of these regulations is that bottom trawl fishing is now prohibited in $90 \%$ $\left(739,491 \mathrm{~km}^{2}\right)$ of ocean waters in the United States West Coast Exclusive Economic Zone, including $32.6 \%$ of shelf $(<200 \mathrm{~m}$ ) depth zones and $56.0 \%$ of upper slope depth zones (200-1,280 m), with a disproportionate focus on priority habitat features that are proxies for fish habitat, sensitivity to bottom trawling, and biodiversity. The final spatial management measures include 53 new or modified habitat conservation areas closed to bottom trawling in fishable depths $(<1,280 \mathrm{~m})$ and a precautionary prohibition on all bottom contact fishing gears at depths greater than $3,500 \mathrm{~m}$. Together the final set of habitat conservation area closures and openings result in an overall increase in coastwide protections for hard, mixed, and soft substrates; seamounts; submarine canyons; and known and predicted coral, sponge, and pennatulid locations. Finer scale analyses indicate net increases or no change in coral and sponge observations inside protected areas across all regions and depth zones, despite some reductions in total area and hard substrate protected in certain regions. Based on historic bottom trawl effort data, we estimate that the opening of previously closed areas restores $24.6 \%$ of fishing effort that was displaced by bottom trawl closures implemented prior to 2020. Here we describe the involvement and approach of the conservation organization, Oceana, to protect seafloor habitats off the United States West Coast, which included a coastwide proposal to modify conservation areas, geospatial analyses, grassroots 
organizing, media stories, and scientific expeditions using remotely operated vehicles. Our comparison of the new versus previous assemblage of habitat conservation areas demonstrates increased overall habitat protection and fishing opportunities throughout depths and bioregions off the United States West Coast.

Keywords: deep-sea corals, marine conservation, bottom trawling, seafloor, fishing, habitat conservation, ecosystem-based management, precautionary

\section{INTRODUCTION}

Protecting ocean habitats is an integral part of responsible fishery management for ensuring long-term sustainable and productive fisheries, vibrant coastal communities and healthy marine ecosystems (Pikitch et al., 2004). Deep-sea coral and sponge ecosystems are important to the biodiversity of the oceans and create complex structures on the seafloor that are used as habitat for recreationally and commercially important groundfish species (Husebo et al., 2002; Heifetz, 2002; Krieger and Wing, 2002). Groundfish are targeted with a variety of fixed (e.g., trap, bottom longline, trammel nets, gill nets) and mobile (e.g., trawl) fishing gear types. The adverse impacts of bottom trawling on seafloor habitats are well documented including reductions in habitat complexity, productivity, diversity and alteration of seafloor community structure (National Research Council (NRC), 2002). Deep-sea corals can be extremely slowgrowing and include the oldest known animals identified to date on Earth (i.e., Roark et al., 2009 aged Leiopathes sp. deep-sea corals at 4,265 years old). Adverse impacts to these habitats may last for decades, rendering such impacts irreversible on time scales relevant to management (Girard et al., 2018; Clark et al., 2019). Deep-sea ecosystems are exceptionally vulnerable to longterm fisheries impacts due to species at these depths exhibiting slow growth, low fecundity, and longevity (Koslow et al., 2000; Williams et al., 2010). Due to the lag time in detecting impacts to fish populations from habitat loss, scientific experts have called for a precautionary approach to manage the impacts of bottom trawling particularly for deep-sea corals and sponges because of their long recovery times (Drinkwater, 2004; Althaus et al., 2009; Hourigan, 2009).

In the Pacific Ocean United States West Coast region off California, Oregon and Washington, groundfish fisheries are managed by the Pacific Fishery Management Council (council) and National Marine Fisheries Service (NMFS). The MagnusonStevens Fishery Conservation and Management Act (MSA) ${ }^{1}$ requires NMFS and regional fishery management councils (councils) to "describe and identify essential fish habitat" (EFH) and "minimize to the extent practicable adverse effects on such habitat caused by fishing," while also identifying "other actions to encourage the conservation and enhancement of such habitat ${ }^{2}$." $\mathrm{EFH}$ is defined as "those waters and substrate necessary to fish for spawning, breeding, feeding or growth to maturity ${ }^{3}$." To protect $\mathrm{EFH}$, councils are required to "prevent, mitigate,

\footnotetext{
${ }^{1} 16$ U.S.C. $\$ 1801$ et seq.

${ }^{2} 16$ U.S.C. $\$ 1853(\mathrm{a})(7)$

${ }^{3} I$. at $\$ 1802(\mathrm{a})(10)$
}

or minimize any adverse effects from fishing, to the extent practicable, if there is evidence that a fishing activity adversely affects EFH in a manner that is more than minimal and not temporary in nature. ". Beyond EFH requirements, councils have clear and varied authority under the MSA to incorporate habitat protections into fishery management plans (FMP). Notably, the "conservation and management" called for in the MSA is defined broadly to include measures to "rebuild, restore, or maintain any fishery resource and the marine environment $t^{5}$," and intended to "assure that irreversible or long-term adverse effects on fishery resources and the marine environment are avoided ${ }^{6}$." Furthermore, the fishery resources referred to in the definition of conservation and management are also defined in the MSA to include "any species of fish, and any habitat of fish ${ }^{7}$."

The first protections for EFH from fishing off the United States West Coast were indirectly initiated in 2000, when NMFS determined that nine groundfish species were overfished, and subsequently implemented rebuilding plans that included decreased catch limits, closed areas, and other measures (Pacific Fishery Management Council (PFMC), 2019). As part of the rebuilding plans, in 2002 NMFS implemented yearround rockfish conservation areas (RCAs) closed to bottom trawl fishing at depth ranges where overfished rockfish species (Sebastes spp.) were most abundant spanning the entire United States West Coast region. Even though trawl RCAs were not intended to protect seafloor habitats, a core section of the coastwide trawl RCA $\left(11,457 \mathrm{~km}^{2}\right)$, largely closed since 2004, served to protect both overfished rockfish and the underlying habitat. The trawl RCAs were intended to be in place until the overfished populations were successfully rebuilt (NMFS, 2014).

In 2006, after an extensive scientific and stakeholder process and based on a unanimous recommendation by the Pacific Fishery Management Council, NMFS implemented Amendment 19 to its Pacific Coast Groundfish Fishery Management Plan to minimize adverse impacts to EFH. This action partially froze the footprint of bottom trawling by closing all areas deeper than $1,280 \mathrm{~m}$ (700 fathoms) and up to $3,500 \mathrm{~m}$, and protected a vast network of 51 areas within the footprint of bottom trawling based on known priority habitats, together totaling $353,500 \mathrm{~km}^{2}$ (Shester and Warrenchuk, 2007). NMFS did not approve the part of Amendment 19 that would have prohibited bottom trawling in waters deeper than $3,500 \mathrm{~m}$, claiming that it did not have

\footnotetext{
${ }^{4} 50$ C.F.R. $\$ 600.815(\mathrm{a})(2)(\mathrm{ii})$

${ }^{5} 16$ U.S.C. $\$ 1802(\mathrm{a})(5)(\mathrm{A})$

${ }^{6} I d$. at $\$ 1802(\mathrm{a})(5)(\mathrm{B})(\mathrm{ii})$

${ }^{7}$ Id. at $\$ 1802(\mathrm{a})(15)$
} 
authority to close areas that were not EFH for managed species (Lohn, 2006).

Freezing the footprint means closing areas not currently fished. While it can be implemented in different ways, the general approach to freezing the footprint is to identify the existing spatial extent of fishing effort and close all areas outside this extent to prevent fishing effort expansion into new areas. Here the seaward depth limit of 1,280 m was set based on the depth below which most United States West Coast bottom trawl effort took place prior to 2006. This depth limit was considered a compromise, however, as the industry identified previous trawl tows and a desire to fish to depths up to $1,829 \mathrm{~m}(1,000$ fathoms). While such an approach protects areas not currently impacted by bottom trawling, freezing the footprint of bottom trawling sets a precautionary policy that new areas should not be trawled until research is conducted and vulnerable habitats identified and protected. It prevents expansion of trawling in the future when technology or market changes could make fishing in such areas economically viable. While freezing the footprint may not reduce current impacts, it is a critical policy tool to reverse the burden of proof in fishery management and prevent future impacts to otherwise pristine areas that have not yet been fished. Freezing the footprint is recognized among the best practices for managing the impacts of bottom trawling (McConnaughey et al., 2020).

After NMFS finalized Amendment 19, the United States Congress in 2007 reinforced long-standing conservation and management authorities under the MSA by adding provisions that further detailed the broad discretion of regional fishery management councils to protect ocean ecosystems from fishing impacts $^{8}$. These discretionary provisions describe councils' authority to "designate zones where fishing shall be limited, or shall not be permitted", to "designate such zones to protect deep sea corals from physical damage from fishing gear ${ }^{10}$," and to "include management measures ... to conserve target and nontarget species and habitats, considering the variety of ecological factors affecting fishery populations ${ }^{11}$."

Based on these clarifying statutory provisions and scientific advancements in understanding the distribution and ecological roles of deep-sea coral ecosystems, the conservation nongovernmental organization (NGO) Oceana sought policy improvements upon the original set of closed areas implemented under Amendment 19. The objective was to redesign the configuration of protected areas of the United States West Coast region to further protect $\mathrm{EFH}$ within the bottom trawl footprint as well as close all waters deeper than $3,500 \mathrm{~m}$ to bottom trawling to close remaining areas not currently fished, hence more effectively freezing the bottom trawl footprint.

Conservation approaches to protect seafloor habitats from bottom trawling bring together the science of the effects of bottom trawling (Watling and Norse, 1998; National Research Council (NRC), 2002) with ecosystem-based approaches

\footnotetext{
${ }^{8} 16$ U.S.C. $\$ 1853(\mathrm{~b})$

${ }^{9} I d$. at $\$ 1853(\mathrm{~b})(2)(\mathrm{A})$

${ }^{10} I d$. at $\$ 1853(\mathrm{~b})(2)(\mathrm{B})$

${ }^{11} I$ d. at $\$ 1853(\mathrm{~b})(12)$
}

to marine spatial planning (Foley et al., 2010). Successful place-based approaches include consideration of physical and biological conditions and features with socio-economic impacts (Crowder and Norse, 2008). Given the uncertainties of the location and extent of important and vulnerable ocean habitat features, marine conservation planning should follow the precautionary principle and seek to reverse the burden of proof (Dayton, 1998).

Several geospatial tools have been used to inform decisions on marine protected areas. Sharp and Watters (2011) conducted GIS analysis of alternative marine protected area scenarios presented by governments for the Ross Sea region of Antarctica that was used as the basis for management measures. Geange et al. (2017) developed conservation planning software as a decision-support tool to generate scenarios that maximize the representation of different habitat types, while minimizing costs to affected user groups. Spatially explicit annealing tools such as MARXAN (Ball and Possingham, 2000) have widely been used to generate optimized scenarios for terrestrial and marine protected areas to optimize habitat representation within cost constraints. MarineMAP was used as a decision-support tool during the California state waters marine protected areas process, enabling stakeholders to conduct their own geospatial analysis of alternative protected area designs and submit proposals to decision-makers (Merrifield et al., 2013). Leathwick et al. (2008) used statistical learning and conservation prioritization to analyze a range of marine protected area scenarios, identifying cost-effective scenarios with greater conservation benefits and less costs to fishers than scenarios proposed by fishers. Several studies use sophisticated geospatial tools to demonstrate potential win-win scenarios; however, these were not integrated into a participatory planning process and were not implemented in regulation (Leathwick et al., 2008; Geange et al., 2017). Gleason et al. (2010) described a successful stakeholder process using science guidelines and geospatial planning tools to establish marine protected areas in California state waters.

The term "win-win" is frequently used in ecosystem service and international development literature to refer to actions that deliver better outcomes for people and the environment, or for biodiversity and ecosystem services (McShane et al., 2011). Howe et al. (2018) concluded from a meta-analysis that tradeoffs are more common than synergies, that there is no generalized context for win-wins and urged against attempting to achieve win-wins. Xiao et al. (2018) found that the potential for winwins for biodiversity and ecosystem services is dependent on ecological factors, specifically the trophic levels of the species providing the ecosystem services. Here we define a win-win as policy changes that result in increased habitat conservation and increased fishing opportunities relative to the status quo, assessed at both coastwide (overall) and bioregional (depth and latitude) scales. We attempt to demonstrate that a win-win for deep-sea ocean habitats and fisheries was achieved off the United States West Coast. This win-win was made possible by building upon the fishery council's precautionary freeze the footprint approach to seafloor habitat protection, legal changes clarifying its authority to protect deep-sea coral ecosystems, improvements in the scientific understanding of the location 
and extent of seafloor habitat features, a successful adaptive management approach, and an open public process.

\section{MATERIALS AND METHODS}

\section{Stakeholder Process \\ Essential Fish Habitat Five Year Review}

Under United States law, NMFS and fishery management councils are required to review their EFH regulations at least every five years to ensure they are meeting management goals and are based on the best scientific information available ${ }^{12}$. In September 2010, the Pacific Fishery Management Council initiated its first groundfish EFH five-year review. The review took place in three phases: (1) data collection, (2) data synthesis and a public request for proposals to modify EFH designation or conservation, and, if warranted, (3) a groundfish fishery management plan amendment process based on the phase 1 data and phase 2 proposals. The council first established an ad hoc EFH review committee including scientists, fishing representatives and the conservation NGOs Oceana and EcoTrust. The committee reviewed and compiled existing data into a publicly available EFH data catalog, issued requests for new relevant data, and drafted a request for proposed changes to EFH designations, conservation and management. Upon completion of the first two phases, including receipt of six proposals from the public and two proposals from National Marine Sanctuaries, and based on recommendations from its review committee, the council determined it would proceed with phase 3 and consider changes to its Pacific Coast Groundfish Fishery Management Plan.

\section{The Oceana Proposal}

In response to the council's EFH review and call for proposals, Oceana, Ocean Conservancy, and Natural Resources Defense Council submitted a coastwide comprehensive conservation proposal to amend $\mathrm{EFH}$ designations, conservation measures and enforcement (Oceana et al., 2013). Beginning in 2011, Oceana met with tribes, fishers, fishing representatives and other stakeholders coastwide, as well as members of the council and its advisory committees, NMFS managers and scientists, West Coast National Marine Sanctuary managers, and state fish and wildlife agencies to inform the conservation proposal. This outreach continued during the development of the proposal and after it was submitted. The overall goal of the proposal was to protect vulnerable and sensitive seafloor habitats from the primary threat of bottom trawl fishing gear while supporting and maintaining fishing opportunities. We designed and advocated for a comprehensive coastwide approach to prohibit the geographic expansion of bottom trawling, protect areas with sensitive and diverse seafloor habitats, and minimize fishing effort displacement.

We used publicly available spatial data compiled for the fishery council's EFH review to identify areas that warrant protection from bottom trawling

${ }^{12} 50$ C.F.R. $\$ \$ 600.815(\mathrm{a})(1)(\mathrm{ii})(\mathrm{B}), 600.815(\mathrm{a})(10)$ and $600.815(\mathrm{~b})$
(NOAA and Oregon State University (OSU), 2012). Our approach differed from other approaches by prioritizing a unique set of habitat features and indicators of vulnerability to fishing with the primary constraint being displaced trawl effort. Other approaches such as spatial annealing algorithms attempt to secure a minimum target percentage of various habitat types constrained by total area. With Geographic Information System (GIS) data and analysis, we identified areas known to contain priority habitat features sensitive to bottom trawl impacts, including hard substrate, biogenic habitats, submarine canyons, ridges, banks and escarpments. Priority habitat features were defined in the fishery council process to be synonymous with "complex sensitive habitats" including physical features like rocky reefs and living habitat features like deep-sea corals (Class Anthozoa), sponges (Phylum Porifera), and sea pens (Order Pennatulacea) (NMFS, 2019a).

We identified areas with high regional coral and/or sponge bycatch, known priority habitat features, and areas currently subject to very low or no trawl effort (Figure 1). We also prioritized known habitat features within the boundaries of National Marine Sanctuaries and included areas proposed by Greater Farallones National Marine Sanctuary and Monterey Bay National Marine Sanctuary. We analyzed bottom trawl fishing effort data to avoid areas of high importance to the fishery and to assess potential economic costs in terms of potential fishing effort displacement. Unlike approaches that identify areas based on computer algorithms, we drew boundaries that would include the priority habitat features, while attempting to simplify proposed conservation area boundaries to aid in enforcement. By hand drawing boundaries in GIS, we were able to explain the specific rationale for each new or modified conservation area boundary. We mapped and analyzed our proposal at coastwide (e.g., all ocean waters off the states of California, Oregon, and Washington from the shoreline to $370 \mathrm{~km}$ offshore) and nine biogeographic and depth-based scales as defined in NMFS (2013): 0-200 m, 200-1,280 $\mathrm{m}$, and $>1,280 \mathrm{~m}$ depth zones, each divided into southern (Mexico/United States border to Point Conception), central (Cape Mendocino to Point Conception), and northern (Canada/United States border to Cape Mendocino). We analyzed and compared our proposal to alternative proposals under consideration and presented our comparative analyses to the council to inform their final decision.

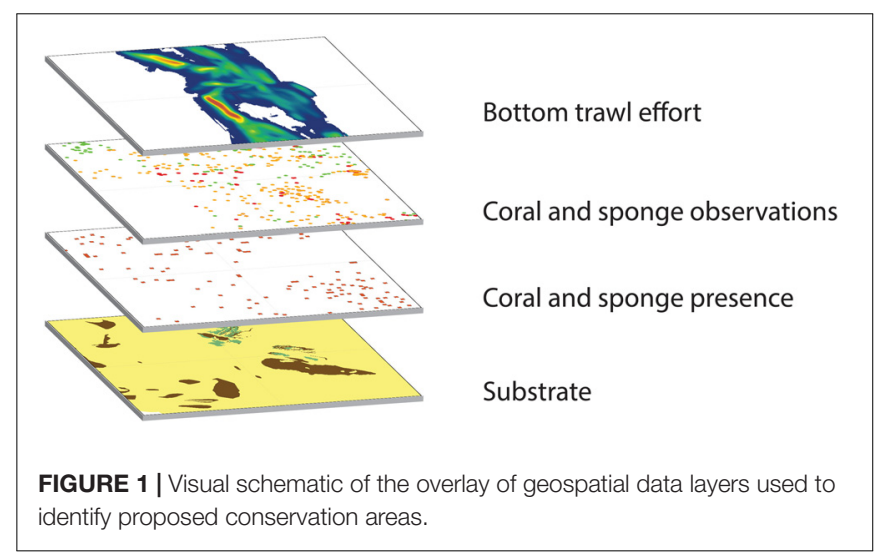


Our Oceana et al. (2013) conservation proposal included 65 new or modified EFH conservation areas in depths shallower than $1,280 \mathrm{~m}$ to be closed to bottom trawling off the outer coast of Washington, Oregon, and California. The largest proposed conservation area was for the Southern California Bight, encompassing $42,581 \mathrm{~km}^{2}$ of the region's offshore banks, reefs and numerous deep-sea corals and sponges that stretch from Point Conception to the United States-Mexico border (Salgado et al., 2018). Our proposal included nine partial re-openings of existing EFH conservation areas off central and northern California, most of which we agreed to as part of the Monterey Bay National Marine Sanctuary collaborative proposal process, described below.

In addition, we proposed protecting the deep-sea ecosystem off California $(>3,500 \mathrm{~m}$ ) from future potential bottom fishing. While bottom fishing is not currently conducted at these depths and does not appear economically viable in the foreseeable future, we proposed this potentially pristine area be protected consistent with the precautionary freeze the footprint approach and to set a precedent for other potential threats such as deepsea mining. In 2006, NMFS disapproved a previous fishery council recommendation to protect this area because it was not first designated as groundfish EFH based on the lack of fishery resources at these depths. We therefore articulated in our proposal the agency's legal foundation for protecting this area using either its MSA authorities to protect $\mathrm{EFH}$ or discretionary MSA authorities that allow fishery councils and the agency to designate closed areas, protect deep-sea corals, and conserve target and non-target fish species and habitats. While there have been very few biological surveys at these depths, the proposal referenced 195 distinct coral observations from within the proposed area deeper than $3,500 \mathrm{~m}$, including the black coral Bathypathes alternata, the stony coral Fungiacyathus marenzelleri, the gorgonian coral Chrysogorgia sp., the mushroom soft coral Anthomastus robustus and the bamboo corals Keratoisis sp. and Lepidisis sp. (Oceana et al., 2013). Finally, our proposal included improvements to the enforcement of conservation areas, principally changing vessel monitoring system transmission rates from one to four times per hour to more precisely indicate fishing vessel locations in relation to closed areas and enable more fine-scale enforcement.

\section{Monterey Bay National Marine Sanctuary Collaborative Proposal}

In late 2012, the Monterey Bay National Marine Sanctuary convened local stakeholders from the bottom trawl fleet and the conservation community to discuss potential changes to EFH closed areas within the central portion of the Sanctuary's boundaries. The premise was to attempt to rearrange $\mathrm{EFH}$ conservation area boundaries on a relatively local scale so that all stakeholders would see a net benefit. The stakeholders involved in this process defined a win-win outcome as a new set of regulatory boundaries that the fishing community would consider an improvement in their portfolio of fishing opportunities and conservation groups would consider an overall improvement to habitat protections. Stakeholders used available physical and biogenic habitat spatial data as well as other information such as fishing records and logbooks to develop proposal concepts. Stakeholders also considered opening portions of existing bottom trawl closures. As a general principle, areas containing known sensitive habitat types (e.g., hard substrate, coral, and sponge records) were not considered for reopening, and areas of high current bottom trawl fishing effort were not considered for closure. The Sanctuary conducted a quantitative GIS analysis to show how the coverage of different habitat types would change under various proposal concepts. Relying on this analysis, the group was ultimately able to submit to the Pacific Fishery Management Council a consensus proposal that achieved the group's desired win-win outcome (de Beukelaer et al., 2016). We incorporated this proposal for the subset of the coast within the central Monterey Bay National Marine Sanctuary into the Oceana et al. (2013) coastwide proposal.

\section{Collaborative Proposal and the Trawl Rockfish Conservation Area}

After all proposals were submitted, a group of stakeholders including members of the fishing industry and the conservation NGOs Natural Resources Defense Council and Environmental Defense Fund requested that the council pause its EFH amendment process while they attempted to develop a joint coastwide proposal. In Atkinson et al. (2016), the group ultimately submitted what was termed the "collaborative" proposal to both modify and designate new EFH conservation areas and remove the coastwide trawl RCA. This collaborative proposal did not include recommendations for the Southern California Bight, central Oregon, or the deep sea (>3,500 m depth).

The council later decided to modify the scope of its action to also consider the removal of the core trawl RCAs closed year-round to bottom trawling. In response to the successful recovery of several overfished rockfish populations, the council recommended in 2013 that the year-round trawl RCA off Northern California and Oregon be removed. After receiving public comments, including from Oceana, NMFS determined that there was an insufficient basis to remove this trawl RCA prior to the conclusion of the council's groundfish EFH fishery management plan amendment. Before removing the trawl RCA, the council needed to first consider whether the underlying habitat features should remain protected from bottom trawling.

The council then structured the groundfish fishery management plan process - Amendment 28 to the Pacific Coast Groundfish Fishery Management Plan - to address three primary issues. First, the council adopted a range of alternatives to designate new or modified EFH conservation areas closed to bottom trawling. The council included both the Oceana and collaborative group proposals as distinct alternatives in its range of possible EFH actions, but it removed from consideration any proposed changes within Tribal Usual and Accustomed fishing areas off the outer Washington coast. All concepts from the Monterey Bay National Marine Sanctuary and Greater Farallones National Marine Sanctuary proposals were included in the Oceana and/or collaborative group proposals, so were not included as distinct alternatives. The council also removed from consideration any changes inside state Territorial Sea 
boundaries (shore to three nautical miles). Second, the council considered alternatives to remove the trawl RCA. Third, based on Oceana's proposal, the council considered alternatives to protect the deep-sea ecosystem off California $(>3,500 \mathrm{~m})$ from all commercial fishing gears that contact the seafloor (including bottom trawl, bottom longline, or trap fishing gear), using its discretionary MSA authorities. The Council and NMFS authored an environmental impact statement as required under the United States National Environmental Policy Act that analyzed the environmental impacts of each of these alternatives individually and cumulatively (NMFS, 2019a).

\section{Conservation Approaches and Public Engagement \\ Scientific Synthesis and Geospatial Analysis}

Fundamentally, the use of a common data set endorsed by the government, scientists and stakeholders provided common ground, and helped prevent the process from becoming solely a political negotiation. Oceana conducted and submitted geospatial analyses comparing the regulatory protections in place at the time with the new proposals and alternatives. Our analyses identified gaps in current protections based on new data that had become available since the $2006 \mathrm{EFH}$ measures were put in place. For each proposal, we assessed net changes in coverage for each habitat type and feature associated. The combined analyses of cumulative trawl RCA changes and EFH conservation area changes provided novel information for decision-makers that would have been obscured by EFH and RCA changes viewed in isolation. It also enabled NMFS to conduct a thorough analysis of the effects of reopening the trawl RCA and simultaneously designate additional EFH conservation areas within and outside the trawl RCA to avoid adverse impacts to EFH. NMFS adopted this objective analytical framework for examining cumulative impacts of combined EFH and RCA changes in their environmental impact statement used for decision-making (NMFS, 2019a). At fishery council meetings and in comments to NMFS, we aimed to ensure that any re-openings of existing conservation areas were accompanied by new or expanded EFH conservation areas such that there would be a cumulative increase in total area and priority habitat features protected on both regional and coastwide scales.

\section{At-Sea Expeditions}

We collected new data on the location of priority habitat features, groundfish distributions and associations in support of our proposal. We conducted four at-sea expeditions off Oregon and California in 2010, 2011, 2013, and 2016 where we surveyed areas along the shelf or the edges of deep banks a depths from 126 to $379 \mathrm{~m}$ within our proposed EFH conservation areas and collected seafloor habitat data using remotely operated vehicles (Supplementary Figure 1). We submitted scientific reports with our findings to the council and NMFS, documenting new locations of corals and sponges and their co-occurrence with council-managed groundfish (Enticknap et al., 2013; Shester et al., 2017). With high definition video and still images we documented clear associations between managed species and ecologically important and sensitive habitats (Supplementary Figure 2).

The NOAA Deep Sea Coral and Research Technology Program added these coral and sponge observations to the national deep-sea coral database (NOAA National Database for Deep-Sea Corals and Sponges, 2017). The results of our Southern California Bight expedition added an additional 3,289 records of corals, sponges and pennatulids to the database. These records represented a 39\% increase in the combined number of habitatforming invertebrate records in the national database within our proposed Southern California Bight EFH conservation area.

\section{Generating Support via Media, Grassroots, and Communications}

An important pillar to securing ocean habitat protections is public engagement. Through traditional and social media, Oceana and partners reached people from coast to coast and shared with them how deep-sea coral gardens, sponge beds and rocky reefs support a healthy ocean ecosystem. We collected and submitted more than 60,000 on-line signatures by individuals from the United States in support of Oceana's conservation proposal. Oceana developed an online interactive story map using the Story Map Journal application in ArcGIS Online, providing information about deep-sea corals and the specifics of the Oceana proposal ${ }^{13}$. At key milestones such as council decisions and during expeditions, we utilized media stories, opinion editorials and social media platforms to reach a broad audience outside the scope of fishery management.

In addition to public comments from individuals, state and federal elected representatives, scientists, explorers and businesses engaged in the fishery management process. State legislators and Congressional representatives submitted letters urging the fishery council and NMFS to advance seafloor habitat protections. Businesses operating in Southern California joined a letter of support asking fishery managers to adopt Oceana's proposed Southern California Bight EFH conservation area.

\section{Datasets Analyzed}

We compared the final set of habitat protection regulations to year-round bottom trawl closures in place prior to this action using available datasets that would be most relevant to the policy objectives of habitat conservation and fishing opportunity.

\section{Seafloor Substrate Type}

\section{Surficial Geologic Habitat Induration, Version 4.0}

This dataset describes geologic seafloor substrate off the coasts of Washington, Oregon, and California within the United States territorial sea and EEZ (shore to $370-\mathrm{km}$ ) categorized into three main types: hard, mixed and soft. The most recent version includes local-scale data from multiple sites and sources off California, Oregon, and Washington (Oregon State University, Active Tectonic and Seafloor Mapping Lab (OSU), 2018). Hard and mixed (hard and soft) substrates are some of the least abundant benthic habitat types, yet they are among the most important habitats for fishes (NMFS, 2005). Hard substrates are

\footnotetext{
${ }^{13}$ www.oceana.org/PacificSeafloorTour
} 
also the seafloor substrate most sensitive to bottom trawling (National Research Council (NRC), 2002; NMFS, 2005). Areas with hard substrates, particularly those with high topographical relief, are a preferred habitat of large gorgonian corals such as Primnoa sp. and Paragorgia sp. (Watanabe et al., 2009; Tong et al., 2012). Based on observations and known affinity for structure, over 50 species of groundfish use hard bottom substrates at one or more life stages. This dataset currently compiles the best available indicators of hard and mixed substrate types at the finest scale available. While data for deeper areas is less certain, this compilation improved upon previous hard substrate data layers by incorporating new geological surveys at higher resolution.

\section{West Coast Canyons}

This dataset depicts submarine canyons and gullies which were delineated as part of the geologic mapping for the Groundfish EFH review process in 2005 and updated by Oregon State University for areas of northern California, Oregon, and Washington. Boundaries for submarine canyon walls, canyon floors, and gullies were extracted from seafloor habitat data (Oregon State University, Active Tectonic and Seafloor Mapping Lab (OSU), 2004).

\section{Biogenic Habitat}

\section{NOAA Deep-Sea Coral and Sponge Database}

This dataset contains records of known coral, sponge, and pennatulid observations. For this analysis, we selected only those records within the United States territorial sea and EEZ (shore to $370 \mathrm{~km}$ ) off the coast of Washington, Oregon and California (NOAA National Database for Deep-Sea Corals and Sponges, 2017). We used the number of coral and sponge records inside and outside of conservation areas as a proxy for known deepsea coral and sponge habitats and associated diversity. The taxonomic resolution of each record varies by survey method, but this dataset represents the most comprehensive compilation of deep-sea corals and sponge records. It also enables identification of certain types of corals that are known to be exceptionally long-lived, such as Antipatharians (black corals).

\section{Coral, Sponge, and Pennatulid Presence}

These data layers summarize presence of deep-sea corals (Class Anthozoa), sponges (Phylum Porifera), and sea pens and sea whips (Order Pennatulacea) off the United States Pacific coast. Presence data were aggregated within contiguous $1 \times 1 \mathrm{~km}$ cells from a database of point records of coral, sponge, and pennatulid occurrence compiled by NOAA's Deep-Sea Coral Research and Technology Program (NOAA Map Service, 2018). These data complement the point data on coral and sponge occurrence by equally weighting each $1 \times 1 \mathrm{~km}$ cell regardless of the number of occurrences within each cell. This presence/absence dataset provides a different proxy for coral and sponge habitat that offsets the effects of unequal sampling effort.

\section{Predicted Deep-Sea Coral Habitat Suitability for the United States West Coast}

This dataset depicts regional-scale habitat suitability based on predictive models of deep-sea corals for the United States West Coast off Washington, Oregon and California. Deep-sea coral habitat suitability was modeled at a $500 \times 500 \mathrm{~m}$ spatial resolution and is based on factors known to influence deep-sea coral distribution such as substrate, slope, temperature, salinity and others. Summed data were ranked from 0 to 4 , with 4 being the highest predicted coral habitat suitability. For our analysis, we used only areas categorized at level 4 (Guinotte and Davies, 2014). While observational data is generally preferred in surveyed areas, this dataset helps augment the overall understanding of coral and sponge habitat in unsurveyed areas. We report the analysis as a Supplementary Dataset to the observational data to address the uncertainty in true coral and sponge distribution due to the lack of comprehensive surveys.

\section{Bottom Trawl Fishing Effort}

As a proxy for the fishing opportunity represented by the availability of areas open to bottom trawling, we examined the distribution of bottom trawl fishing effort in the five years prior to the original EFH conservation areas implemented under Amendment 19 to the Pacific Coast Groundfish FMP. In the 2006 Amendment 19 final decision, NMFS adopted a metric of displaced fishing effort - the amount of fishing effort that took place in new closures - and determined that Amendment 19 was practicable based on a relatively low amount of displaced effort. This data layer depicts the relative intensity of commercial bottom trawling off the United States West Coast from January 1, 2002 through June 11, 2006 (NOAA, 2015). This dataset includes records from the Pacific Fisheries Information Network (PacFIN) database for all bottom trawl gear types excluding state-managed trawl fisheries. Data for the state-managed California halibut fishery is the one exception because data from that fishery is submitted to PacFIN and is therefore included in this dataset. The cell values in the raster dataset are in $\mathrm{km} / \mathrm{km}^{2}$ where each cell represents the total length of all towlines intersecting a standard area. These values are based on a line density algorithm where the value for each raster cell is the quotient of total towline segments intersecting a $3-\mathrm{km}$ radius circular search area centered on a $500 \times 500 \mathrm{~m}$ grid cell (NOAA, 2015). We compared the displaced 2002-2006 fishing effort between the baseline closures and the final action to estimate the previously displaced fishing opportunities to the United States West Coast bottom trawl fishing fleet that were restored with implementation of Amendment 28. We used the 2002-2006 time span to represent fishing effort prior to the initial baseline set of regulations to determine the effort displaced by the baseline set of closures and assess changes in access to the displaced trawl effort resulting from the conservation area changes.

\section{Yelloweye rockfish occurrence}

This dataset depicts the probability of occurrence of yelloweye rockfish (Sebastes rubberimus) off the coast of Washington, Oregon, and California out to the 1,600-meter isobath. The probability is the result of a model output which provides the predicted probability of observing at least one yelloweye rockfish at the center of a $2 \times 2 \mathrm{~km}$ grid cell. The probability at each point is the average probability of occurrence across all years from 2003 to 2011. The model is based on relationships between habitat characteristics such as depth, bottom temperature, sediment 
grain size, distance to rocky substrate and the actual observed occurrence of species in the West Coast Trawl Survey (Northwest Fisheries Science Center (NWFSC), 2011). This data provides a proxy for the known habitat preferences of a sensitive groundfish species that is rebuilding from overfishing.

\section{Spatial Analysis Methods}

We analyzed each of the above datasets at multiple spatial scales to compare the status quo regulations (year-round bottom trawl closures in place from June 11, 2006 to December 31, 2019) to the new regulations that took effect January 1, 2020. To create the "baseline" shapefile for analysis, we merged together the existing year-round conservation areas closed to bottom trawling, including all existing EFH bottom trawl closures seaward of the 700 fathom $(1,280 \mathrm{~m})$ depth contour, EFH conservation areas, state water closures (e.g., state marine protected areas closed to bottom trawling), the Western Cowcod Conservation Area, the Cordell Bank Groundfish Conservation Area, and the yearround, coastwide trawl RCA. The shapefile for "final action" analysis was created starting with the baseline shapefile (all existing closures mentioned above) and using the erase tool in ArcMap to subtract all sections of the trawl RCA being reopened off California and Oregon, then again erasing all final action EFH conservation areas being reopened, and finally using the merge tool to add in all final action EFH conservation area closures including the deep-water conservation area.

Analysis was completed in the projected coordinate system WGS 1984 UTM Zone 10N. We used this coordinate system because data were originally provided by NMFS in the EFH catalog ${ }^{14}$ in this coordinate system. Because area calculations can differ, sometimes greatly, when calculating areas between coordinate systems, all analyses within the United States West Coast EEZ were conducted using WGS 1984 UTM Zone 10N to ensure consistency and comparability between analyses. All analysis was completed using Environmental System Research Institute's (ESRI) ArcGIS Desktop, ArcMap, version 10.6.1.

\section{Geographic area analysis}

Using shapefiles with the baseline closures and final action closures, each dataset was analyzed within each of 11 geographic areas to quantify the amount of each dataset (area or number of features) inside and outside of closures. These geographic areas included three large bioregions (Northern, Central, Southern), each divided into two depth zones: (a) continental shelf (coastline to continental shelf break), approximately $200 \mathrm{~m}$ depth; and (b) upper slope, the shelf break to 1,280 m (NMFS, 2013). We also analyzed the baseline and final action changes within four National Marine Sanctuaries off California (Greater Farallones National Marine Sanctuary, Cordell Bank National Marine Sanctuary, Monterey Bay National Marine Sanctuary and Channel Islands National Marine Sanctuary) and within the United States West Coast territorial sea and EEZ (shore to $370 \mathrm{~km}$ ). We did not analyze the Olympic Coast National Marine Sanctuary as a distinct geographic area because no changes were considered in that Sanctuary. Within those 11 geographic areas, we analyzed each dataset both inside and outside of existing

\footnotetext{
${ }^{14}$ https://www.webapps.nwfsc.noaa.gov/data/efh-catalog/
}

EFH closures under the baseline and final action closures. Vector datasets (all except for bottom trawl effort) were analyzed using the Tabulate Intersection tool in ArcGIS. Raster datasets (bottom trawl effort) were analyzed using the Zonal Statistics as Table tool in the Spatial Analyst toolbar in ArcGIS.

\section{Rockfish conservation area analysis}

We analyzed the year-round trawl RCA as a distinct geographic feature to fully understand the changes to the RCA as a result of the final Amendment 28 action. Two analyses were completed for the RCA: one analysis of all datasets within the year-round coastwide trawl RCA as of 2019, and one analysis of all datasets within the area opened under the final action as of January 1 , 2020 (the trawl RCA off Oregon and California excluding new and existing EFH conservation areas and areas within California's state marine waters that will remain closed to bottom trawling under state law). Similar to the biogeographic regions analysis, we analyzed vector datasets (all except for bottom trawl effort) using the Tabulate Intersection tool. We analyzed raster datasets (bottom trawl effort) using the Zonal Statistics as Table tool in the Spatial Analyst toolbar.

\section{Individual habitat conservation area analysis}

We analyzed each of 72 distinct habitat conservation area changes made under the Amendment 28 final action including 53 new or modified EFH conservation areas, one EFH conservation area correction (to shift the Potato Bank EFH conservation area to its correct location off Southern California), 17 areas that were re-opened to trawling, and the Deep-sea Ecosystem Conservation Area closed to all commercial bottom contact fishing gears. Each change is categorized as either an additional closed area ("close") or a portion of a previous EFH conservation area that was removed ("reopen"). As outlined in both the biogeographic regions and RCA GIS analyses, vector datasets (all except for bottom trawl effort) were analyzed using the Tabulate Intersection tool. Raster datasets (bottom trawl effort) were analyzed using the Zonal Statistics as Table tool in the Spatial Analyst toolbar.

\section{Continental scale analysis of bottom trawl closures}

To view the new suite of conservation areas in the context of the broader trend of bottom trawl closures off the West Coast of North America, we calculated the total area of year-round bottom trawl closures within the EEZs of the United States off Alaska and the Canadian EEZ off British Columbia using the projected NAD 1983 Alaska Albers coordinate system and the United States West Coast region using the projected coordinate system WGS 1984 UTM Zone 10N, including each nation's territorial sea. In addition to the United States West Coast bottom trawl closures analyzed in the final action shapefile, the analysis of closed areas to bottom trawling includes the 1998 closure of the Eastern Gulf of Alaska off Southeast Alaska, the 2006 closure of the Aleutian Islands off Alaska, the 2006 and 2008 actions in the Bering Sea, the 2009 closure of the United States Arctic to commercial fishing, and the 2012 bottom trawl footprint closure off British Columbia, Canada (North Pacific Fishery Management Council (NPFMC), 2009, 2018, 2019; Wallace et al., 2015; Department of Fisheries and Oceans Canada (DFO), 2019). Due 
to lack of consistent habitat feature datasets across these regions, this component of the analysis only examined total area closed to bottom trawling.

\section{RESULTS}

\section{Coastwide Analysis of Final Action and Regulations}

In April 2018, following an extensive public process and environmental review, the Pacific Fishery Management Council took final action on its range of alternatives to modify EFH conservation areas, the trawl RCA, and the protection of the deep-sea ecosystem off the United States West Coast. In a unanimous decision, the council recommended a suite of changes to regulatory bottom trawl closed areas with a net increase of $363,513 \mathrm{~km}^{2}$ of federal ocean waters off the United States West Coast $(5-370 \mathrm{~km}$ ) (Figure 2 and Supplementary Figure 3). First, the fishery council's final set of actions included recommendations for 53 new and modified EFH conservation areas closed to bottom trawling while opening 16 distinct areas within existing EFH conservation areas and opening one area within the bottom trawl footprint closure off Northern California. Second, the council voted to remove the trawl RCA off Oregon and California, while keeping the RCA closed off Washington. However, off Oregon and California, sections of the area formerly within the trawl RCA remained closed to bottom trawling due to overlap with new and existing EFH conservation areas or state-waters closed to trawling. Third, the council voted to protect the deep-sea ecosystem off California $(>3,500 \mathrm{~m})$ from all bottom contact fishing gears. Changes to conservation area enforcement capabilities by increasing required vessel monitoring system ping rates from one to four pings per hour, consistent with the Oceana et al. (2013) proposal were implemented in separate regulations that took effect July 13 , 2020 (NMFS, 2020).

The council's recommendations were then transmitted to NMFS and the United States Secretary of Commerce who oversees NMFS for review and rulemaking. This regulatory process included finalizing an environmental impact statement, approving the proposed fishery management plan amendment text, and submitting proposed amendments and regulations for public review. NMFS approved the fishery management plan amendment in September 2019 and on November 19, 2019, issued final regulations implementing the new and modified $\mathrm{EFH}$ conservation areas, the opening of the trawl RCA off Oregon and California, and the protection of the deep-sea ecosystem off California (NMFS, 2019b; Figure 2). The final rule closely reflected the recommendations of the fishery council, including an expanded conservation area for a glass sponge reef north of Grays Canyon off the outer Washington coast. This change made at the time of the final rule was done to better align Oceana's original proposed conservation area for this reef with the 2018 adjudicated seaward boundary of the Quinault Indian Nation's Usual and Accustomed fishing area, consistent with the intent of the fishery council's recommendation. The new habitat conservation areas and modifications took effect on January 1, 2020.

The Amendment 28 Pacific Coast Groundfish Fishery Management Plan final action and rulemaking:

1. Designated 53 new and modified EFH conservation areas closed to bottom trawling within currently fishable depths, adding $45,136 \mathrm{~km}^{2}$ and removing $638 \mathrm{~km}^{2}$ of currently designated conservation areas with a net increase of $44,498 \mathrm{~km}^{2}$;

2. Removed $7,086 \mathrm{~km}^{2}$ of the year-round trawl RCA off Oregon and California, while keeping $4,371 \mathrm{~km}^{2}$ of the year-round trawl RCA closed in the area off Washington and in certain places off Oregon and California where the RCA overlaps with new and existing EFH conservation areas or state-waters closed to trawling;

3. Established a Deep-Sea Ecosystem Conservation Area off California prohibiting all bottom contact fishing gears in waters deeper than $3,500 \mathrm{~m}$ in an area totaling $319,015 \mathrm{~km}^{2}$. Bottom contact fishing gears include but are not limited to bottom trawl, dredge, and fixed gears like bottom longline, trap or pot, set net, and stationary hook-and-line gears.

Overall, the final action results in a net increase of $363,513 \mathrm{~km}^{2}$ of total habitat conservation areas closed to bottom trawling (Table 1). While the total area includes much deep-sea area beyond currently trawlable depths, it includes substantial increases in total area and priority habitat features protected at fishable depths $(<1,280 \mathrm{~m})$. In addition, the final action significantly increased the proportion of all priority habitats protected from bottom trawling throughout United States West Coast ocean waters, including all physical features and substrate types and all biogenic features (Figures 2, 3). Accounting for these new conservation area closures and openings, plus all existing conservation areas closed year-round to bottom trawling, 739,491 $\mathrm{km}^{2}$ of ocean waters off the United States West Coast (shore to $370 \mathrm{~km}$ ) are now protected from bottom trawling. This amounts to $90 \%$ of all state and federal ocean waters in this region.

\section{Regional Analysis of Final Action and Regulations}

While the additional area of new EFH conservation areas is far greater than the EFH conservation areas reopened to bottom trawling (Table 1), the removal of the trawl rockfish conservation area resulted in a net loss of total area protected in the shelf and upper slope depth ranges of the Northern and Central Bioregions (Table 2). There were substantial increases in upper slope protections in the Southern bioregion. However, since most reopened areas were exclusively soft sediment habitats and new EFH areas focused on priority habitats, there was still a net increase in most priority habitat types (e.g., corals and sponges, hard substrate) in the upper slope and shelf (Figure 3C and Table 2). In the northern upper slope ( 200-1,280 m depth) off Northern California, Oregon, and Washington, the final action resulted in a net loss in the protection of area and a net loss in protection for some priority habitat features like 


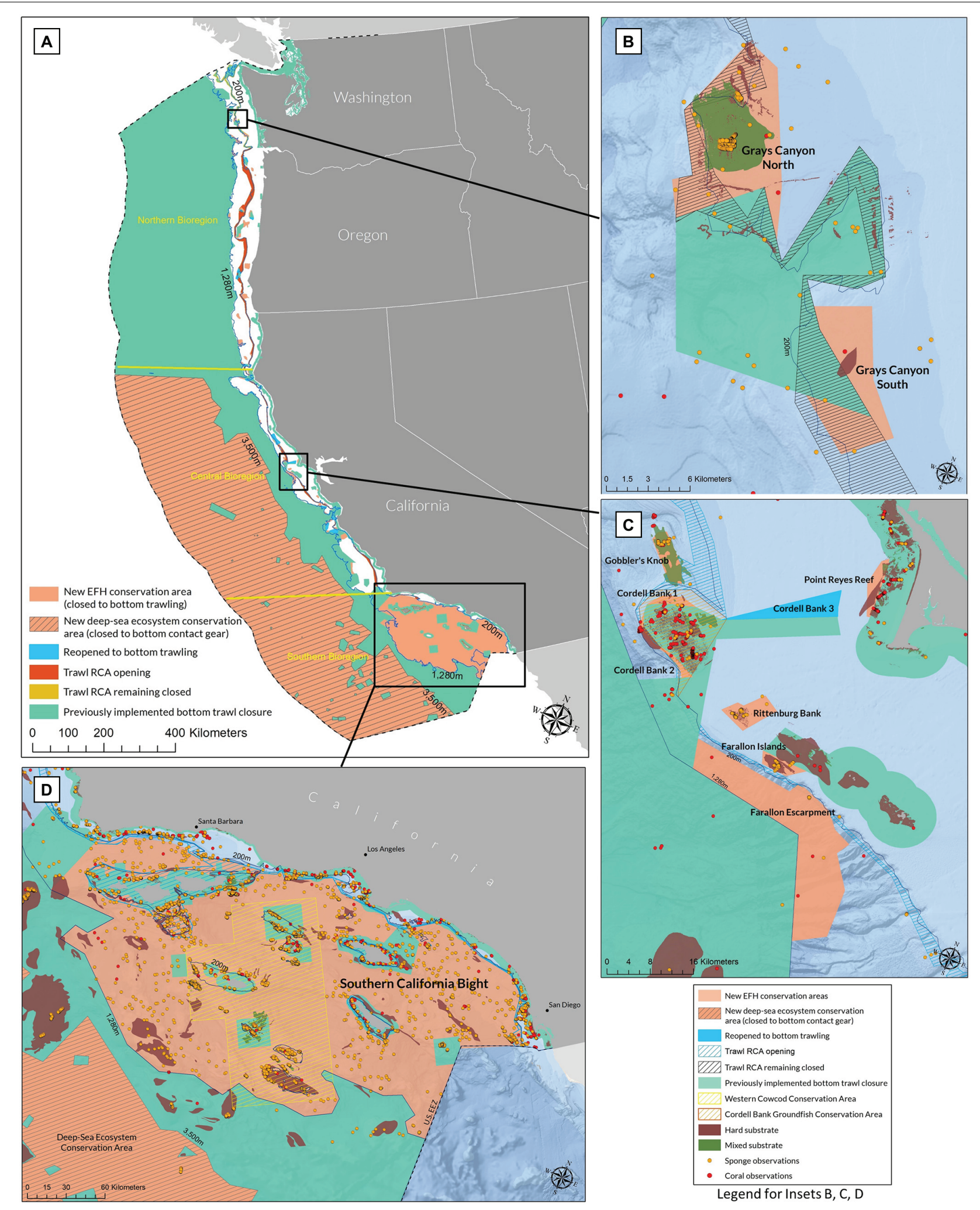

FIGURE 2 | (A) Map of United States West Coast EEZ showing changes to bottom contact fishing regulations resulting from Amendment 28 final action. (B) (Upper Inset) Grays Canyon region. (C) (Center Inset) Farallon Islands/Cordell Bank Region (D) (Lower Inset) Southern California Bight. 
TABLE 1 | Summary of changes to habitat conservation areas in the United States West Coast region resulting from implementation of Amendment 28 to the Pacific Coast Groundfish Fishery Management Plan.

\begin{tabular}{lc}
\hline Habitat Conservation Areas & Area $\mathbf{( k m}^{\mathbf{2}} \mathbf{~}$ \\
\hline New EFH conservation areas (no bottom trawling) & 45,136 \\
Deep-sea ecosystem conservation area (no bottom contact & 319,015 \\
fishing gear) & 638 \\
EFH conservation area openings & 363,513 \\
Net change &
\end{tabular}

rocky reef, but an increase in the protection of observed corals and sponges (Figure 4A). This outcome resulted from opening the trawl RCA off Oregon and California while adding new protections in several areas with high coral and sponge presence. The final action resulted in significant gains in the upper slope of the southern biogeographic region with the adoption of the Southern California Bight EFH conservation area $\left(41,915 \mathrm{~km}^{2}\right)$ (Figure 4B). The final action increased the number of coral and sponge occurrence locations inside bottom trawl closed areas in five of the six shelf and slope bioregions and no change in the Southern shelf bioregion (Figure 5A). In addition, the regulations increased the number of known coral and sponge occurrences within closed areas to bottom trawling in all four California National Marine Sanctuaries, with the greatest gains in the Greater Farallones National Marine Sanctuary (Figure 5B). Notably, despite the removal of the trawl RCA, $99.8 \%$ of the Channel Islands National Marine Sanctuary is now within EFH conservation areas and state marine protected areas, providing durable protection from bottom trawling within this Sanctuary.

Along with the overall increase in protections for biogenic habitat features and rocky reefs, the final action resulted in a net increase in bottom trawl fishing opportunities as measured by the change in 2002-2006 bottom trawl effort displaced by closed areas. By reopening the trawl RCA and certain portions of EFH conservation areas where bottom trawling historically occurred, less historic bottom trawling is displaced by the final action set of closures. Considering the proportion of total bottom trawl effort that occurred in the five years prior to the implementation of Amendment 19, and taking into account both the new openings and closures, we estimate that coastwide, the combined set of actions restored $24.6 \%$ of the historic fishing effort that was previously displaced (Figure $\mathbf{6}$ and Table 3). There is also a net increase in fishing opportunities in each bioregion and within each of the three Central Coast National Marine Sanctuaries, with the greatest gains in the Northern and Central Upper Slope (Table 3). Most of these gains in fishing opportunity resulted from reopening the trawl RCA. These quantitative results are consistent with public statements by fishing industry representatives, Pacific Fishery Management Council members, other stakeholders, and independent experts ${ }^{15}$.

\footnotetext{
${ }^{15}$ See, for example: https://sustainablefisheries-uw.org/new-california-protectedareas-are-excellent-displays-of-fishery-management/; https://www.seattletimes. $\mathrm{com} /$ seattle-news/conservationists-west-coast-bottom-fishermen-embracegrand-bargain/; https://www.santacruzsentinel.com/2019/07/02/oceana-looksfor-public-support-to-protect-ocean-floor-life-in-monterey-bay/;
}

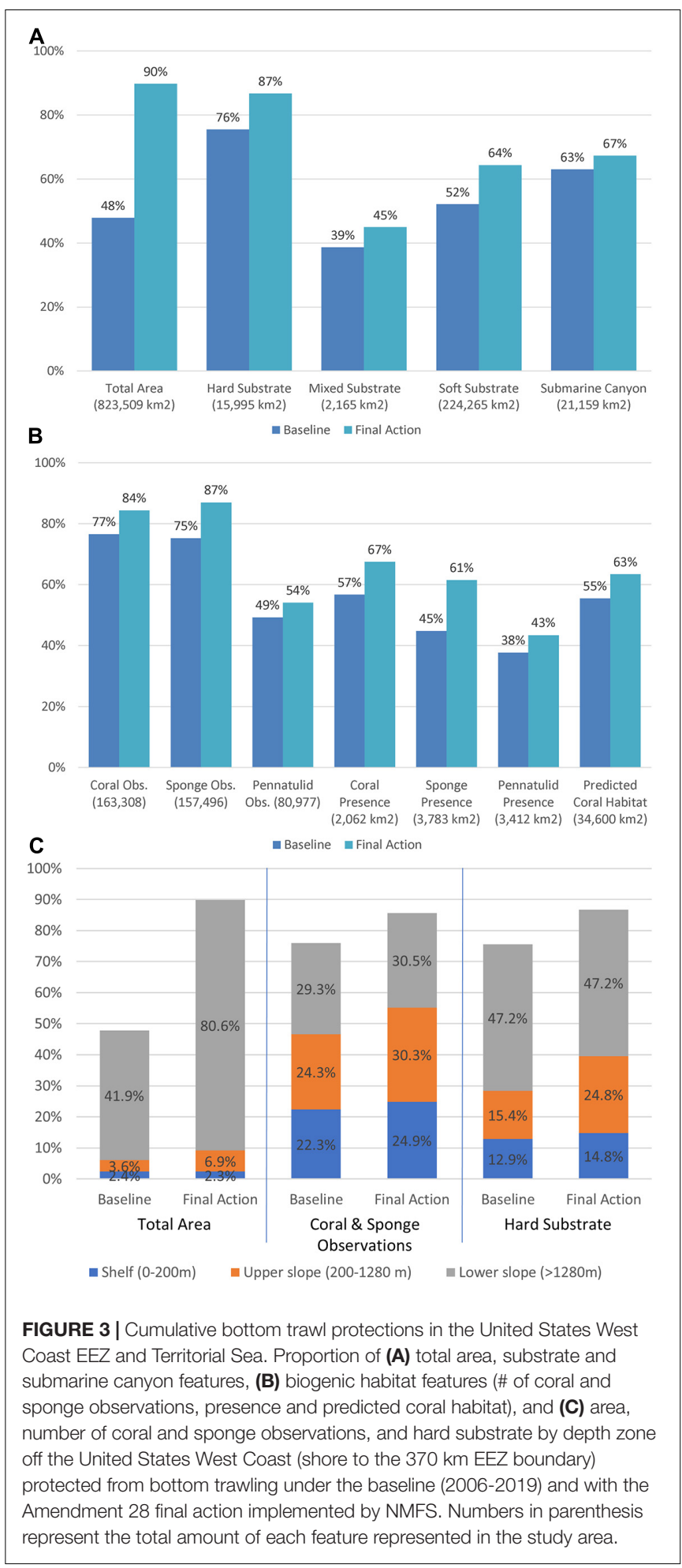

Our analysis specific to the trawl RCA indicates that Amendment 28 maintained $37.2 \%$ of the total area of the trawl RCA that was closed prior to the action within closed areas,

https://www.sfchronicle.com/environment/article/Bottom-trawling-fishingseverely-restricted-off-14844917.php 
TABLE 2 | Geographic area analysis with results from full United States West Coast EEZ (shoreline to $370 \mathrm{~km}$ offshore); all six combinations of Northern, Central and Southern bioregions with shelf (0 to $200 \mathrm{~m}$ ) and upper slope (200 to 1,280 m) depth zones; and the four National Marine Sanctuaries off California.

\begin{tabular}{|c|c|c|c|c|c|c|c|c|}
\hline \multirow[t]{2}{*}{ Geographic Area } & \multicolumn{2}{|c|}{ Area $\left(\mathbf{k m}^{2}\right)$} & \multicolumn{2}{|c|}{ Coral and Sponge Observations (\#) } & \multicolumn{2}{|c|}{ Hard substrate $\left(\mathrm{km}^{2}\right)$} & \multicolumn{2}{|c|}{ Submarine Canyon $\left(\mathbf{k m}^{2}\right)$} \\
\hline & Baseline & Final Action & Baseline & Final Action & Baseline & Final Action & Baseline & Final Action \\
\hline United States West Coast EEZ (shore to $370 \mathrm{~km}$ ) & & 823,509 & & 320,804 & & $15,994.7$ & & $21,159.1$ \\
\hline Inside bottom trawl closure & 394,134 & 739,491 & 243,493 & 274,815 & $12,077.8$ & $13,878.4$ & $13,339.8$ & $14,240.6$ \\
\hline Outside & 429,375 & 84,018 & 77,311 & 45,989 & $3,916.9$ & $2,116.3$ & $7,819.3$ & $6,918.5$ \\
\hline Northern Bioregion - Upper Slope & & 30,153 & & 44,003 & & 174.4 & & $6,613.2$ \\
\hline Inside bottom trawl closure & 5,742 & 3,431 & 19,805 & 32,040 & 74.3 & 55.4 & $1,327.2$ & $1,499.3$ \\
\hline Outside & 24,411 & 26,722 & 24,198 & 11,963 & 100.2 & 119.1 & $5,286.0$ & $5,113.9$ \\
\hline Northern Bioregion - Shelf & & 33,985 & & 21,783 & & $1,639.9$ & & 127.0 \\
\hline Inside bottom trawl closure & 6,420 & 6,363 & 482 & 4,159 & 660.7 & 891.6 & 65.0 & 64.7 \\
\hline Outside & 27,565 & 27,622 & 21,301 & 17,624 & 979.1 & 748.2 & 62.0 & 62.3 \\
\hline Central Bioregion - Upper Slope & & 23,872 & & 16,879 & & $2,605.1$ & & $2,376.5$ \\
\hline Inside bottom trawl closure & 7,281 & 6,897 & 12,436 & 14,735 & $1,366.8$ & $1,489.9$ & 687.6 & 740.2 \\
\hline Outside & 16,591 & 16,975 & 4,443 & 2,144 & $1,238.3$ & $1,115.2$ & $1,688.9$ & $1,636.3$ \\
\hline Central Bioregion - Shelf & & 17,132 & & 56,273 & & $1,051.7$ & & 122.4 \\
\hline Inside bottom trawl closure & 7,246 & 6,952 & 50,553 & 55,074 & 945.7 & $1,014.2$ & 118.5 & 118.6 \\
\hline Outside & 9,886 & 10,180 & 5,720 & 1,199 & 106.0 & 37.5 & 3.9 & 3.8 \\
\hline Southern Bioregion - Upper Slope & & 46,747 & & 52,289 & & $2,422.4$ & & $1,184.7$ \\
\hline Inside bottom trawl closure & 16,885 & 46,146 & 45,697 & 50,441 & $1,023.7$ & $2,414.8$ & 442.6 & $1,117.7$ \\
\hline Outside & 29,862 & 601 & 6,592 & 1,848 & $1,398.7$ & 7.6 & 742.1 & 67.0 \\
\hline Southern Bioregion - Shelf & & 7,761 & & 28,344 & & 521.3 & & 57.0 \\
\hline Inside bottom trawl closure & 5,916 & 5,932 & 20,647 & 20,646 & 457.2 & 463.8 & 23.7 & 39.2 \\
\hline Outside & 1,845 & 1,829 & 7,697 & 7,698 & 64.1 & 57.5 & 33.3 & 17.7 \\
\hline Greater Farallones NMS & & 8,534 & & 2,126 & & 251.1 & & 481.1 \\
\hline Inside bottom trawl closure & 4,036 & 4,010 & 884 & 2,059 & 228.1 & 246.6 & 343.2 & 357.6 \\
\hline Outside & 4,499 & 4,524 & 1,242 & 67 & 23.1 & 4.6 & 137.9 & 123.5 \\
\hline Cordell Bank NMS & & 3,330 & & 1,703 & & 43.7 & & 102.0 \\
\hline Inside bottom trawl closure & 2,214 & 2,050 & 1,354 & 1,633 & 40.7 & 42.2 & 61.4 & 61.4 \\
\hline Outside & 1,116 & 1,280 & 349 & 70 & 3.0 & 1.6 & 40.6 & 40.5 \\
\hline Monterey Bay NMS & & 15,779 & & 107,728 & & $1,052.5$ & & $2,908.9$ \\
\hline Inside bottom trawl closure & 9,643 & 9,557 & 99,520 & 103,215 & 942.8 & $1,004.7$ & $2,319.6$ & $2,362.3$ \\
\hline Outside & 6,136 & 6,222 & 8,208 & 4,513 & 109.6 & 47.7 & 589.3 & 546.5 \\
\hline Channel Islands NMS & & 3,807 & & 47,849 & & 240.0 & & 109.8 \\
\hline Inside bottom trawl closure & 3,230 & 3,800 & 47,545 & 47,849 & 230.5 & 240.0 & 78.1 & 109.8 \\
\hline Outside & 576 & 6 & 304 & 0 & 9.5 & 0.0 & 31.7 & 0.0 \\
\hline
\end{tabular}

Total area, number of coral and sponge observations, area of hard substrate, and area of submarine canyon for each of the 11 geographic areas (italicized in shaded rows) is compared with the area inside and outside year-round bottom trawl closed areas under the baseline and final action. Green shaded cells represent increases, orange shaded cells represent decreases, and yellow shaded cells represent no change (less than $1 \%$ of total). 
A $100 \%$
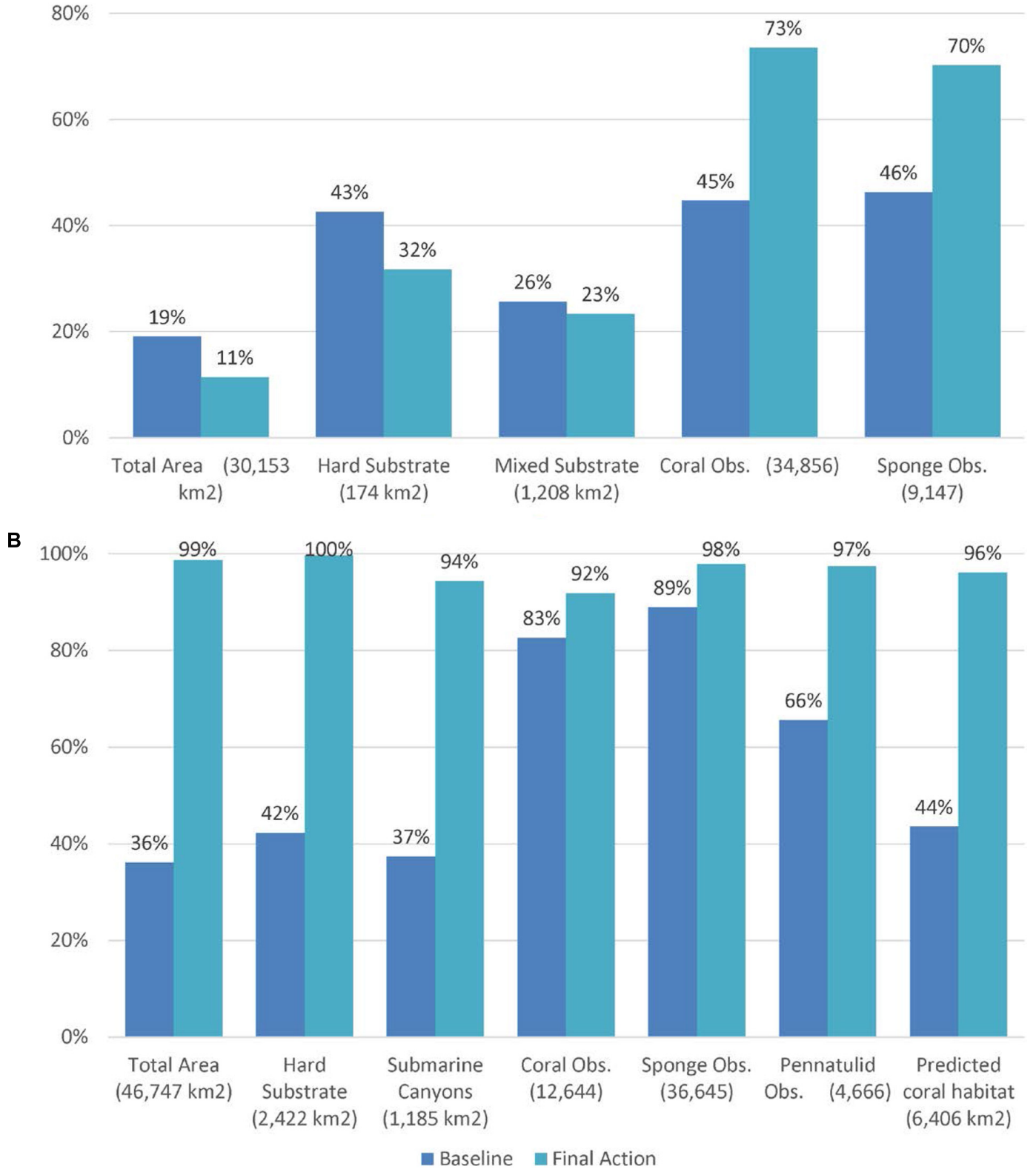

FIGURE 4 | Examples of bioregional analyses of changes in habitat protection coverage. Proportion of total area, hard and mixed substrate and number of coral and sponge observations protected in panels (A) the upper slope of the northern bioregion (Cape Mendocino, CA to the United States/Canada border, 200 to 1,280 m depth) and (B) the upper slope of the southern bioregion ( 200 to 1,280 m depth south of Point Conception, California to the United States/Mexico border) under the baseline (2006-2019), compared with the Amendment 28 final action implemented by NMFS. Numbers in parenthesis represent the total amount of each feature represented within the geographic area analyzed.

representing the sum of the trawl RCA that remains in place off Washington state, areas of the former trawl RCA off California and Oregon that are within new and previously implemented EFH conservation areas, and areas where the trawl RCA overlapped California state waters closed to bottom trawling. Coastwide, $62.8 \%$ of the total RCA area was reopened, containing
$67.5 \%$ of the historic fishing effort that occurred prior to the RCA being closed to bottom trawling (Tables 3, 4). Resulting from the concerted effort to establish new EFH conservation areas in locations within the trawl RCA containing priority habitats, an even greater percentage of hard substrate (51\%), corals (77\%), and sponges $(67 \%)$ in the trawl RCA remained protected despite 
A

$100 \%$

$90 \%$

$80 \%$

$70 \%$

$60 \%$

$50 \%$

$40 \%$

$30 \%$

$20 \%$

$10 \%$

$0 \%$

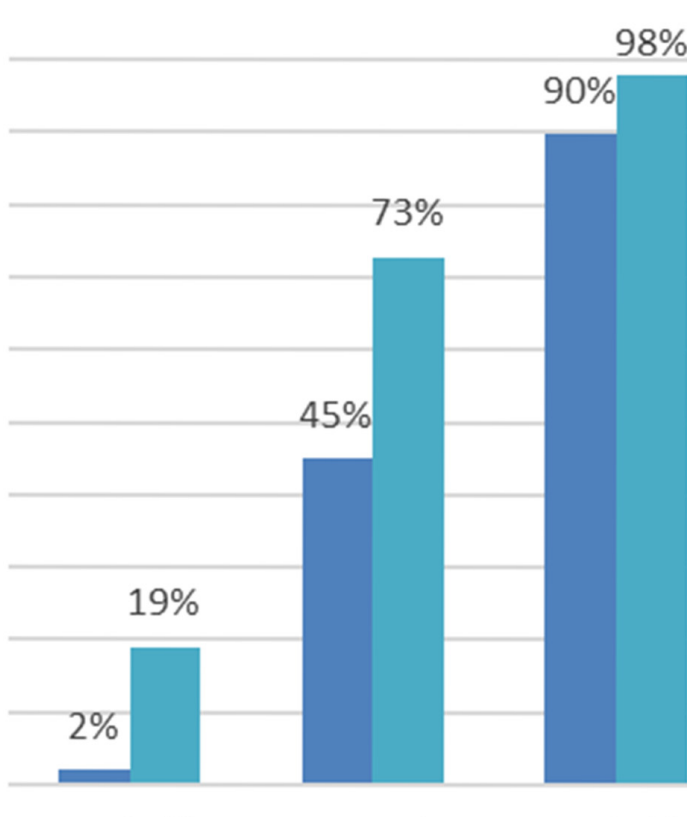

N Shelf N Upper Slope

$(21,783)$

$(44,003)$

C Shelf

$(56,273)$

$98 \%$
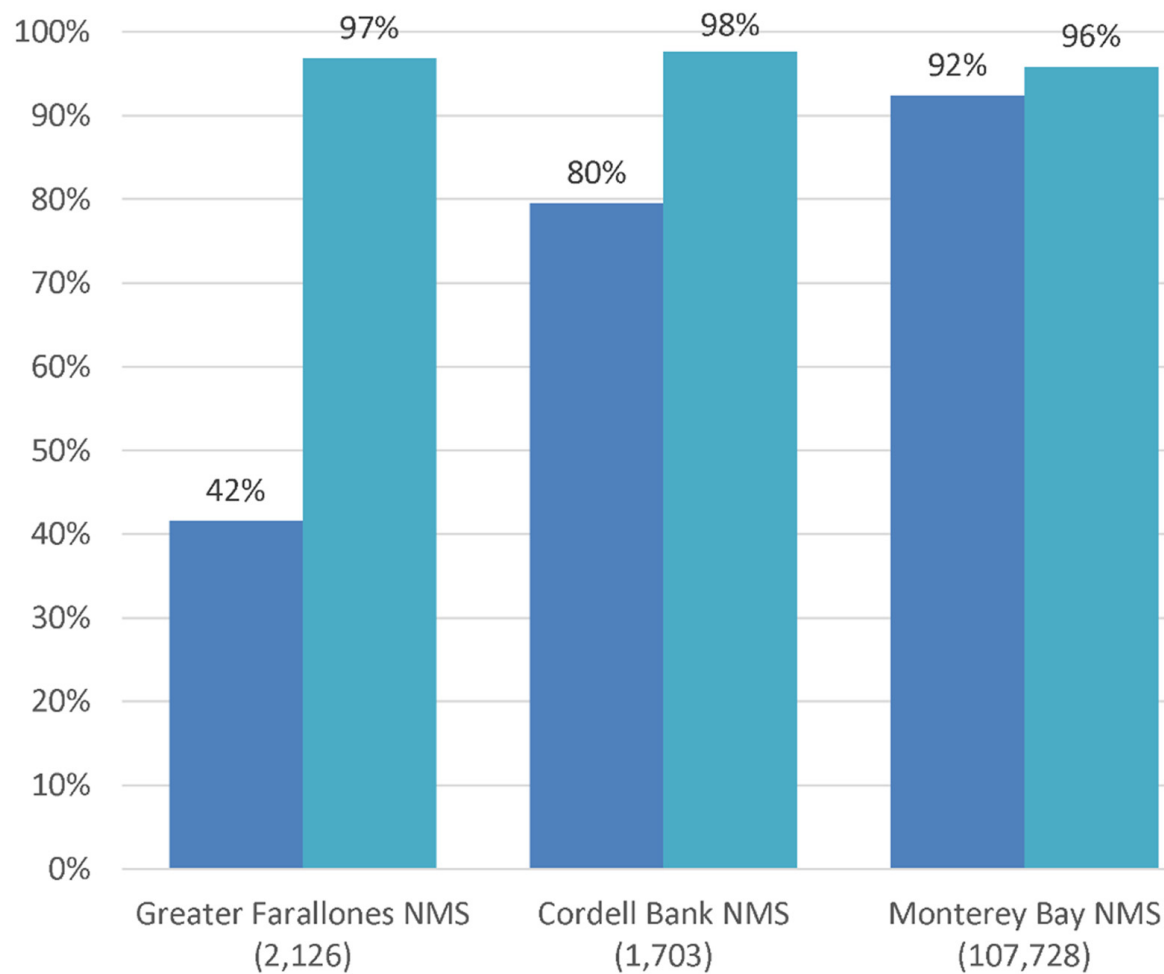

C Upper Slope

$(16,879)$

$(107,728)$

$96 \%$

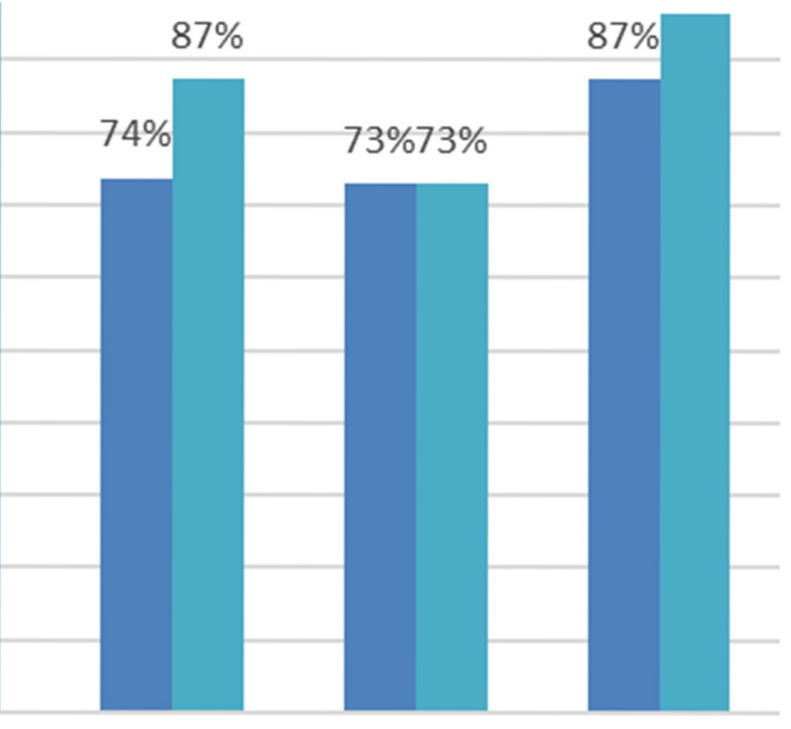

\section{S Shelf}

$(28,344)$

S Upper Slope

$(52,289)$

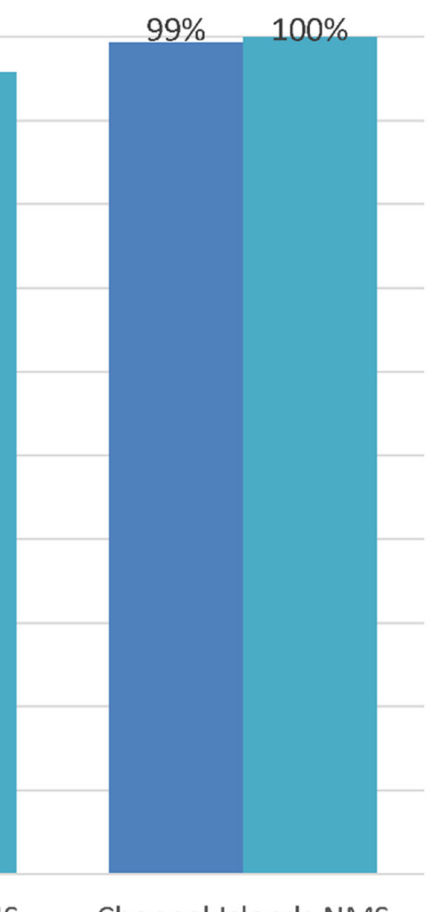

Channel Islands NMS

$(47,849)$

\section{Baseline Einal Action}

FIGURE 5 | Proportion of summed coral and sponge observations inside bottom trawl closures under the baseline (2006-2019) and Amendment 28 final action implemented by NMFS within (A) each of the six bioregions and depth ranges and (B) California National Marine Sanctuaries. Numbers in parenthesis represent the total number of coral and sponge observations in each area. 


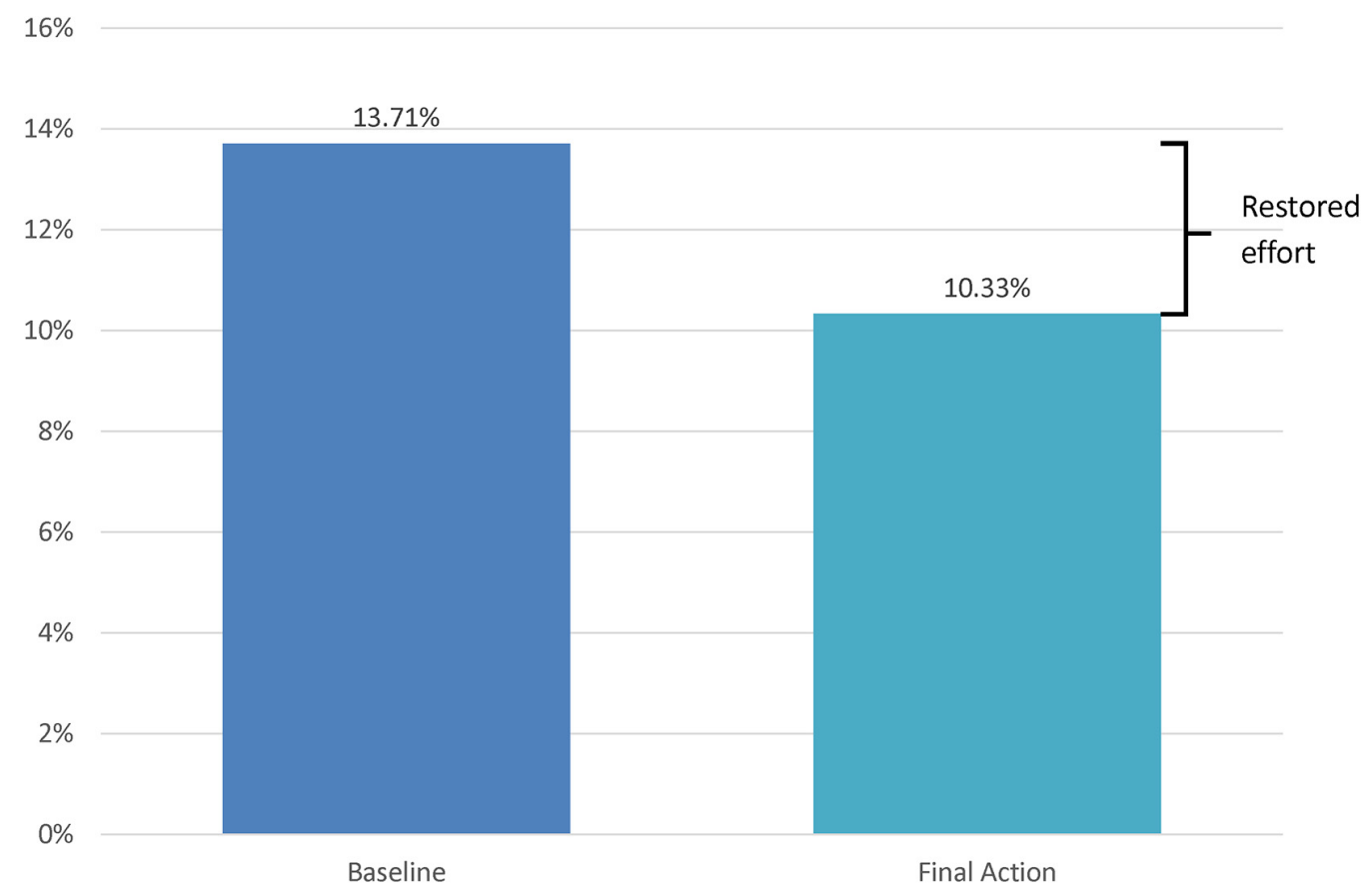

FIGURE 6 | Proportion of 2002-2006 bottom trawl fishing effort displaced under the baseline set of closed areas (2006-2019) and under the Amendment 28 final action regulatory closures. Restored fishing effort is the difference in displaced effort between the baseline and final action.

TABLE 3 | Bottom trawl effort.

\begin{tabular}{|c|c|c|c|c|c|c|}
\hline Geographic Area & Total & Baseline & Final Action & Change & $\%$ Change & $\%$ Restored \\
\hline EEZ + Territorial Sea (shore to 370 km) & $99,429,040$ & $85,795,466$ & $89,155,460$ & $3,359,994$ & $3.4 \%$ & $24.6 \%$ \\
\hline North Bioregion - Upper Slope & $39,678,313$ & $35,583,019$ & $37,737,154$ & $2,154,135$ & $5.4 \%$ & $52.6 \%$ \\
\hline North Bioregion - Shelf & $25,865,827$ & $24,282,738$ & $24,664,664$ & 381,927 & $1.5 \%$ & $24.1 \%$ \\
\hline Cent. Bioregion - Upper Slope & $17,204,171$ & $16,139,906$ & $16,818,382$ & 678,476 & $3.9 \%$ & $63.8 \%$ \\
\hline Cent. Bioregion - Shelf & $10,761,297$ & $5,723,381$ & $5,860,234$ & 136,852 & $1.3 \%$ & $2.7 \%$ \\
\hline South Bioregion - Upper Slope & 118,703 & 85,475 & 88,146 & 2,671 & $2.3 \%$ & $8.0 \%$ \\
\hline South Bioregion - Shelf & $4,624,098$ & $3,976,592$ & $3,979,835$ & 3,243 & $0.1 \%$ & $0.5 \%$ \\
\hline Greater Farallones NMS & $4,883,565$ & $4,189,485$ & $4,293,262$ & 103,777 & $2.1 \%$ & $15.0 \%$ \\
\hline Cordell Bank NMS & $1,182,324$ & 958,285 & $1,044,707$ & 86,422 & $7.3 \%$ & $38.6 \%$ \\
\hline Monterey Bay NMS & $10,344,230$ & $6,137,276$ & $6,449,378$ & 312,102 & $3.0 \%$ & $7.4 \%$ \\
\hline Channel Islands NMS & 10,489 & 3,581 & 3,581 & 0 & $0.0 \%$ & $0.0 \%$ \\
\hline Rockfish Conservation Area & $5,526,097$ & 0 & $3,730,186$ & $3,730,186$ & $67.5 \%$ & $67.5 \%$ \\
\hline
\end{tabular}

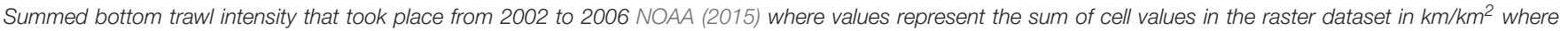

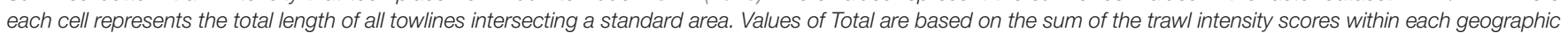

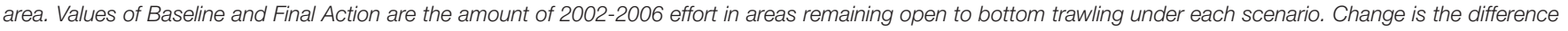
in trawl intensity score between Baseline and Final Action. \% Change is Change/Total. \% restored is Change/(Total-Baseline).

the RCA reopening (Table 4). However, the reopening of the RCA did result in a loss of total area protected in the shelf and upper slope regions (Table 2).

From a fish habitat perspective, the final action largely maintained and increased the overall amount of key habitat used by species of interest. For example, we examined habitat models for yelloweye rockfish (Sebastes ruberrimus), which is the last remaining overfished rockfish species off the United States West Coast still under a rebuilding plan at the time of this publication. The proportion of yelloweye rockfish habitat
( $80 \%$ of the maximum probability of occurrence) inside areas closed year-round to bottom trawl gear increased from 37\% under the baseline (2006-2019 regulations) to 39\% with the Amendment 28 final action (Supplementary Data Table). Even with removal of the trawl RCA off Oregon and California, which was largely designed to close overfished rockfish habitat, the final set of actions resulted in slightly more yelloweye rockfish habitat protected overall. The net increase in yelloweye rockfish habitat protection is explained by the increase in hard substrate protected outside the RCA and the fact that much of the 
TABLE 4 | Total area, area of hard substrate and number of coral and sponge observations within baseline trawl RCA, and within the portions of the trawl RCA that was reopened and the portions that remained closed under the Amendment 28 final action.

\begin{tabular}{|c|c|c|c|c|}
\hline Geographic Area & Area $\left(\mathrm{km}^{2}\right)$ & Hard substrate $\left(\mathrm{km}^{2}\right)$ & \# Coral observations & \# Sponge observations \\
\hline Baseline year-round trawl RCA & $11,456.9$ & 467.6 & 24,718 & 12,709 \\
\hline RCA Opening & $7,085.6$ & 228.5 & 5,657 & 4,236 \\
\hline $\mathrm{RCA}$ remaining closed & $4,371.3$ & 239.1 & 19,061 & 8,473 \\
\hline
\end{tabular}

hard substrate within the RCA remained closed as new EFH conservation areas.

Our analysis of individual changes to EFH conservation areas indicates that new individual closed areas ranged from $1.32 \mathrm{~km}^{2}$ (Shale Pile E.) to $41,914.8 \mathrm{~km}^{2}$ (Southern California Bight). The Southern California Bight EFH conservation area is more than two orders of magnitude larger than the next largest new EFH conservation area (Farallon Escarpment, $327.2 \mathrm{~km}^{2}$ ). Reopenings of EFH conservation areas ranged from $2.43 \mathrm{~km}^{2}$ (South of Mars Cable) to $192.41 \mathrm{~km}^{2}$ (Point Arena S.1) (Supplementary Data Table). The conservation areas with the greatest number of coral occurrences were the Brush Patch $(7,822)$, Samoa Deepwater $(2,069)$, and Southern California Bight $(7,915)$ (Supplementary Data Table). Areas with the highest number of sponge occurrences included Grays Canyon North $(4,369)$, Southern California Bight $(12,764)$, Point Sur Platform $(1,388)$, the Brush Patch $(1,471)$, and outer Soquel Canyon $(1,316)$. While the Farallon Escarpment has relatively few coral and sponge records due to the lack of exploration in the area, it contains a high relative area of predicted coral habitat $\left(297 \mathrm{~km}^{2}\right.$ out of $327 \mathrm{~km}^{2}$ ). Areas of greatest increases in hard substrate included the Southern California Bight $\left(2,211 \mathrm{~km}^{2}\right)$, Heceta Bank North $\left(120 \mathrm{~km}^{2}\right)$, and Big Sur Coast $\left(73 \mathrm{~km}^{2}\right)$. Our full results examining all datasets assessed in each geographic area and within each new or modified individual EFH conservation area can be found in the Supplementary Data Table.

\section{EFH Conservation Area Highlights}

Our results indicated net increases in biogenic habitat features including sensitive areas that are important to commercial and recreational fish. While some of the bioregional analyses indicated net losses in total area protected due to the removal of the rockfish conservation area, the 53 additional conservation areas along the shelf and upper slope represent major advances in habitat and biodiversity conservation based on newly available science (see Supplementary Data Table - Final Area Analysis).

\section{Southern California Bight}

The Southern California Bight encompasses the large region of upper slope and shelf habitat from Point Conception to the Mexico Border, including eight offshore islands and dozens of offshore banks, ridges, and seamounts. Historically and today, the Southern California Bight is an important region for hook and line-based commercial and recreational groundfish fishing. While certain areas within the Bight (Catalina Island, Potato Bank, Cherry Bank) were protected as EFH conservation areas in 2006 , only $36.1 \%$ of the Southern California upper slope depth range (200-1280 m) was previously protected. This left several important habitat areas such as Cortez and Tanner Banks unprotected from bottom trawling. The Southern California EFH Conservation Area increased protections of the upper slope to $98.7 \%$, which included an additional 20,679 records of corals and sponges and $2,211 \mathrm{~km}^{2}$ of hard substrate (Supplementary Data Table). Using a remotely operated vehicle, Oceana surveyed areas off Santa Rosa Island, Santa Barbara Island, and Butterfly Bank and documented new coral and sponge records in areas that had remained open to bottom trawling (Shester et al., 2017). The conservation area protects highly ranked areas for species richness and abundance by Salgado et al. (2018) including West Catalina Island, San Clemente Island, 9-Mile Bank, and Santa Rosa Flats. Deep-water azooxanthellate corals documented in the Southern California Bight include the colorful hydrocoral Stylaster californicus, the reef-building scleractinian coral Lophelia pertusa, and the Christmas tree black coral Antipathes dendrochristos. While there are records of bottom trawling in several areas of the Southern California Bight, recent bottom trawl effort in federal waters occurred close to the mainland. The new conservation area fully subsumes the nearly $11,000 \mathrm{~km}^{2}$ Western Cowcod Conservation Area, which was established to rebuild the overfished cowcod rockfish (Sebastes levis), thus ensuring trawling remains prohibited when catch restrictions in this area are lifted in the future (Figure 2D).

\section{Central and Northern California}

While much soft sediment shelf and upper slope habitat was reopened with the lifting of the trawl rockfish conservation area in this region, the new EFH conservation areas ensure new and continued protections for the known hard substrate and biogenic habitat features that are generally rare and dispersed in this bioregion. The final action established several new EFH conservation areas where newly identified priority habitat features are located. The Russian River EFH conservation area (also known as "The Football") in the Greater Farallones National Marine Sanctuary protected areas surveyed in September 2014 by the NOAA Deep Sea Coral program in which a remotely operated vehicle documented nursery habitats for skates, sharks and rockfish along with Staurocalyptus sp. barrel sponges and a new species of coral Swiftia farallonesica. The Farallon Escarpment EFH conservation area protects a large $327 \mathrm{~km}^{2}$ swath of a unique geological area along the continental slope, where initial surveys confirmed predictions of highly suitable coral habitat (Figure 2C). The new Samoa Reef conservation area is $49 \mathrm{~km}^{2}$ and protects a deepwater (500-1,100 m depth) rocky reef containing over 2,000 coral observations by the Monterey Bay Aquarium Research Institute. Gobblers Knob EFH conservation area protects a newly identified area of mixed substrate near 
Cordell Bank, and otherwise would have reopened along with the lifting of the RCA. Rittenberg Bank and Cochrane Bank EFH conservation areas proposed by the Greater Farallones National Marine Sanctuary protect newly discovered "Christmas tree" black corals (Antipathes dendrochristos) not previously known to have occurred in the region and extensive high density sponge gardens at rocky reefs in the Gulf of the Farallones. Changes to the Cordell Bank EFH conservation area included reopening of soft sediment habitats and expansions of protections around the rocky bank feature, creating a larger buffer around this exceptional habitat feature, plus protections at a variety of depths. The Point Reyes Reef EFH conservation area included the component of a large nearshore rocky reef feature that was previously unprotected in federal waters, ensuring continuous protections from the shoreline and state waters components to the deeper section of the outer reef (Figure 2C and Supplementary Figure 3D).

\section{Arago Reef}

The Arago Reef, located southwest of Cape Arago, Oregon is a large rocky reef complex that stretches across the continental shelf from shore to over $20 \mathrm{~km}$ off the coast, spanning both state and federally managed ocean waters (Supplementary Figure 3B). Here a $173.6 \mathrm{~km}^{2}$ area of the reef located in federal ocean waters is now designated as an EFH conservation area, closed to bottom trawling, spanning a depth range from 40 to $130 \mathrm{~m}$. Using a remotely operated vehicle, Oceana surveyed the area in 2011 and we documented a diverse rocky reef system including 10 different Pacific rockfish species, lingcod (Ophiodon elongatus), and rex sole (Glyptocephalus zachirus), plus corals belonging to orders Gorgonacea (sea fans), Scleractinia (cup corals), and Stylasterina (branching hydrocorals), sponges and other benthic invertebrates (Enticknap et al., 2013). Our ROV surveys brought attention to this unique and little studied nearshore reef system, which became an important part of our conservation proposal in the Northern biogeographic region. While federal fishery managers did not protect the entirety of the reef as we originally proposed, the majority was protected and there is continued interest in extending the conservation area to shore under state jurisdiction.

\section{Grays Canyon Conservation Area Expansion}

On the north side of Grays Canyon, $57 \mathrm{~km}$ offshore of Grays Harbor, Washington on the continental shelf break is a large rocky reef feature including thousands of glass sponges. Glass sponges are known to form complex habitats that influence the structure of the marine biological community and are highly sensitive to bottom trawl impacts (Austin et al., 2007). The immediately adjacent Grays Canyon was designated an EFH conservation area in 2006 and closed to bottom trawling but federal fishery managers declined to adopt two Oceana proposals to protect the reef habitat to the north of the canyon in 2005 and again in 2009. Subsequent field studies confirmed the presence of hard and mixed physical substrates, methane seeps, swarms of krill, as well as large aggregations of sponges, rockfishes and spot prawns (Pandalus platyceros) (Johnson, 2008; Powell et al., 2018). The glass sponge feature was only previously known to be there because of trawl bycatch records recorded by federal fishery observers. The modified Grays Canyon EFH conservation area now protects the dense glass sponge habitat to the north of the canyon. The new area is based on Oceana's third EFH proposal to protect this diverse reef complex, excluding part of the proposal area overlapping the Quinault Indian Nation's Usual and Accustomed fishing area. Our analysis of the expanded EFH conservation area shows it is $66.3 \mathrm{~km}^{2}$ in total area and includes 4,369 sponge observations and $26.68 \mathrm{~km}^{2}$ of rocky reef features. The expansion also includes a $32.63 \mathrm{~km}^{2}$ area that adjoins the Grays Canyon EFH conservation area to the south of the canyon (Figure 2B).

\section{Progress Toward Freezing the Footprint From California to the Arctic}

The increased protections off the United States West Coast contribute to a continental scale implementation of a freeze the footprint approach to bottom trawling across the Western Coast of North America. The existing closures combined with the 2020 United States West Coast action results in $71 \%$ of the total combined EEZ area off Alaska, the United States West Coast, and British Columbia being closed to bottom trawling totaling 3.6 million $\mathrm{km}^{2}$ (Figure 7 and Table 5). While much of this area has not been trawled to date, these protections include substantial protections at fishable depths (e.g., less than $1,280 \mathrm{~m}$ ) and prevent future expansion of bottom trawling into deeper areas. For example, the bottom trawl closures shown off the Aleutian Islands, Alaska include $39.4 \%$ of habitats shallower than $200 \mathrm{~m}$ and $61.6 \%$ of habitats between 200 and $500 \mathrm{~m}$ (Shester and Warrenchuk, 2007). Therefore, these protections are not simply closing areas outside fishable depths. Unlike policy approaches seeking to protect a minimum amount of area with the assumption that the remaining areas are open, the inclusion of vast areas of deepwater is indicative of a freeze the footprint policy approach that closes all areas outside the current bottom trawl footprint. This indicates a growing implementation of the freeze the footprint approach across fishery management jurisdictions in the North Pacific Ocean.

\section{DISCUSSION}

The culmination of nearly a decade of stakeholder meetings, scientific research, analysis and advocacy resulted in $44,498 \mathrm{~km}^{2}$ of new conservation areas at currently trawlable depths shallower than 1,280 $\mathrm{m}$. These areas, containing diverse and fragile seafloor habitats, are now protected from the destructive impacts of bottom trawl fishing gear. Along with precautionary protections for the deep-sea, Amendment 28 designated $363,513 \mathrm{~km}^{2}$ of new habitat conservation areas, which when combined with previous existing protections results in $90 \%$ of the United States EEZ closed to bottom trawling, including $32.6 \%$ of shelf depth zones and $56.0 \%$ of upper slope depth zones. Protected areas within trawlable fishing depths disproportionately focus on priority habitat features that are proxies for fish habitat, sensitivity to bottom trawling, and biodiversity. These actions advance the dual objectives of freezing the bottom trawl footprint 


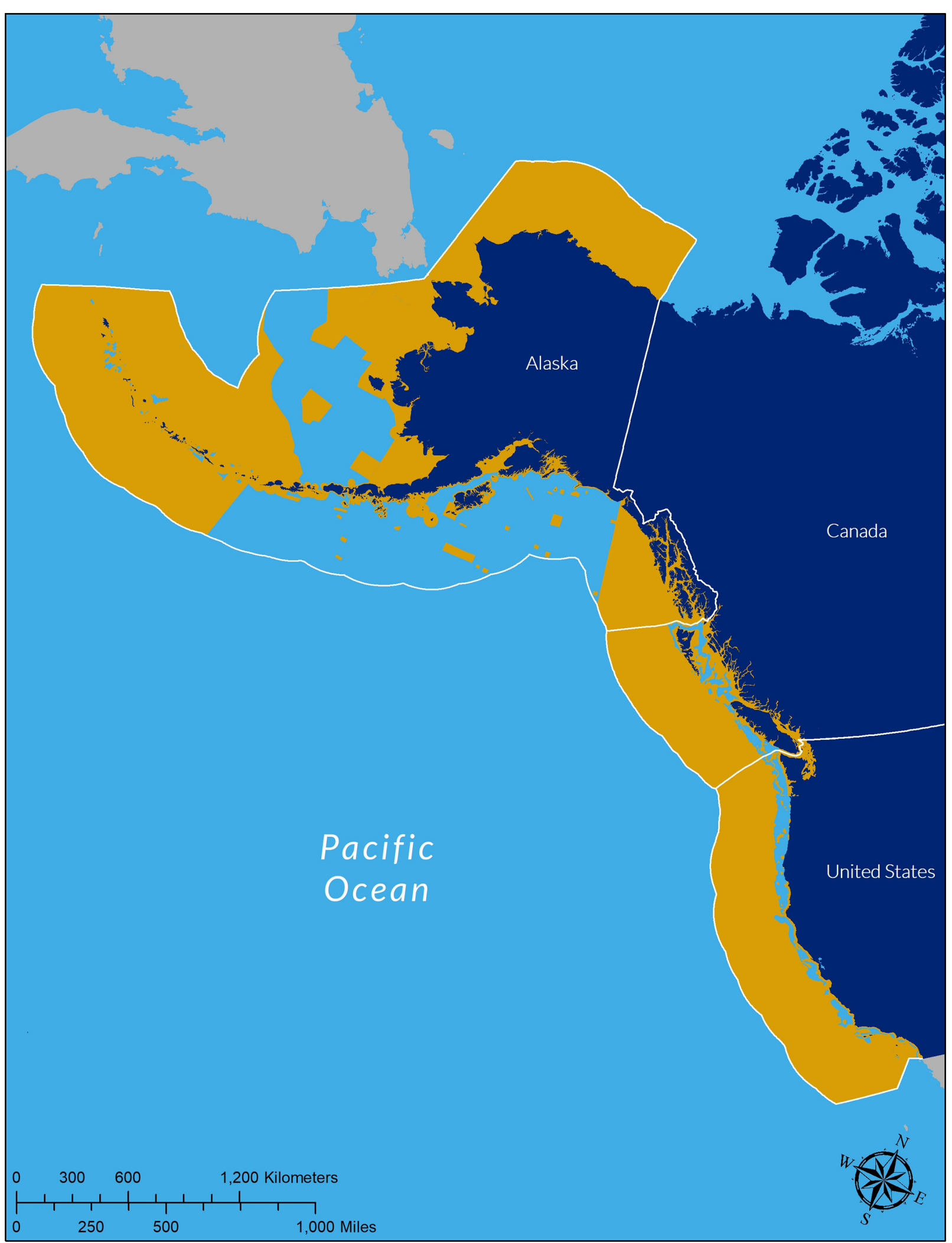

FIGURE 7 | Year-round closures to bottom trawl fishing gear along the western coast of North America from California to the United States Arctic as of January 1 , 2020. In total, bottom trawl closures now cover $71 \%$ of the Exclusive Economic Zones off United States Alaska, British Columbia, Canada and the United States West Coast. Hawaii and Exclusive Economic Zones off Mexico, Russia, and Canadian Arctic are not shown. 
TABLE 5 | Amount and proportion of total Exclusive Economic Zone area off the United States North Pacific (Alaska) Region, Canada Pacific (British Columbia) Region, and United States West Coast Region (Washington, Oregon, CA, United States) closed to bottom trawl fishing as of January 1, 2020.

\begin{tabular}{|c|c|c|c|}
\hline Region & Area closed to bottom trawling $\left(\mathrm{km}^{2}\right)$ & EEZ Area $\left(\mathrm{km}^{2}\right)$ & $\%$ Closed to bottom trawling \\
\hline Alaska & $2,425,041$ & $3,770,021$ & $64 \%$ \\
\hline British Columbia & 425,040 & 454,388 & $94 \%$ \\
\hline United States West Coast & 739,491 & 823,509 & $90 \%$ \\
\hline Total & $3,588,887$ & $5,049,958$ & $71 \%$ \\
\hline
\end{tabular}

and closing sensitive habitat areas within the footprint based on available data.

The newly established Deep-sea Ecosystem Conservation Area off California $(>3,500 \mathrm{~m})$ prohibits all commercial bottom contact fishing gears on a precautionary basis consistent with the freeze the footprint approach. Following discussions regarding the need for deep-sea protections from fishing, fishery managers ultimately moved forward with this precautionary measure referencing the ecological role of the deep sea in trapping greenhouse gases, slowing the rate of climate change, and providing nutrients that fuel fisheries. They also acknowledged that while no fishing currently occurs at these depths, prospective or exploratory bottom contact fishing activities that would otherwise be allowed could damage the deep ocean floor and sensitive deep-sea coral habitats ${ }^{16}$. Bottom contact fishing gear is not currently used at these depths due to limits in current technologies and the absence of economically viable fishery resources. Had a precautionary freeze the footprint approach been implemented prior to the expansion of bottom trawling, countless irreversible impacts to seafloor habitats could have been avoided. This precautionary measure is intended to be both symbolic and proactive in recognition of potential future technological advances and prospective bottom fishing. It illustrates a precautionary precedent for regulations that prohibit other activities that may harm the deep seafloor such as seabed mining or oil and gas exploration, in which potentially sensitive unexplored areas are off limits by default. However, it is critical to avoid disingenuous outcomes that only close areas too deep for fishing and claim credit for conservation wins. That is not the precedent being set here, as the deep-sea protections are part of a comprehensive policy approach that integrates the dual objectives of preventing expansion to new areas while establishing durable protections for sensitive habitats at fishable depths.

In addition to the 53 new and expanded EFH conservation areas designated off California, Oregon and Washington, portions of some existing EFH conservation areas totaling $638 \mathrm{~km}^{2}$ were opened to bottom trawling where there did not exist evidence of priority habitat features. In addition, $7,086 \mathrm{~km}^{2}$ of the trawl RCA was reopened to reflect the rebuilding of previously overfished species and the implementation of individual catch limits to control mortality more directly. Had the RCA reopening occurred independently from decisions regarding EFH conservation areas, there would have been an

\footnotetext{
${ }^{16}$ https://www.federalregister.gov/documents/2019/08/15/2019-16493/ magnuson-stevens-act-provisions-fisheries-off-west-coast-states-pacificcoast-groundfish-fishery
}

even greater loss of total area protected and a net loss of priority habitat features protected from bottom trawling. Offsetting potential losses in habitat protection from reopening the RCA provided additional impetus to include new and expanded EFH conservation areas. Together with the new conservation areas closed to bottom trawling, the reopening of the RCA off Oregon and California and partial reopening of some existing EFH conservation areas resulted in a new configuration of open and closed areas to trawling that restores $25 \%$ of fishing effort that was displaced by bottom trawl closures implemented prior to 2020 . This overall outcome meets the criteria for a "win-win" for ocean habitat conservation and the bottom trawl fishery, however, there were some minor exceptions in certain regions and depth zones that had a net loss of area or loss of priority habitat features protected (e.g., northern upper slope). This conclusion is based on available data that indicates a net increase in bottom trawl fishing opportunities in fishing grounds off Oregon and California, while simultaneously increasing the amount of known coral and sponge habitats throughout all depth zones and bioregions, as well as coastwide throughout West Coast ocean waters. Areas of the seafloor known to have the most diverse and fragile habitats will be protected for future generations, while the fishing community can continue to access and provide an important supply of domestic and exported seafood.

This case study highlights several ways NGO participation can influence the fishery management process. Through the collection of high-definition video and still images, science expeditions provided data on the locations, species and densities of deep-sea habitat including corals and sponges, as well as groundfish species densities and interactions with seafloor habitat features. Some dives conducted with remotely operated vehicles were accomplished in places that had never been explored, informing not only the EFH conservation process but also contributing to the National Deep-Sea Corals and Sponges Database. The involvement of NGOs also ensured broad public attention and public engagement.

The environmental impact statement process under the National Environmental Policy Act provided data-driven, transparent decision-making processes for development and consideration of alternatives and stakeholder input. Oceana provided detailed GIS mapping and an analysis framework to evaluate the cumulative effects of EFH and RCA changes that was used in the stakeholder and decision-making process. GIS tools allowed for fine tune scaling and real-time adjustments following meetings with fishermen, National Marine Sanctuaries, tribes, fishery managers and other stakeholders. It also provided for detailed analysis comparing multiple proposals both on coast-wide and regional scales. In contrast to the use of 
computer generated protected area designs such as MARXAN (Ball and Possingham, 2000), we found that an iterative process to develop proposal boundaries informed by high resolution geographic data on substrate, priority habitat features, and fishing patterns could be more readily explained and discussed with other stakeholders.

Several studies have recommended target percentages for marine protected area coverage (e.g., Sala et al., 2002). While global targets are useful in promoting policy action, we explicitly avoided setting numeric targets for percentage of total area or conservation feature protected and tailored the proposed protections to the context and the opportunities for a win-win outcome. Furthermore, such conservation targets typically leave open all areas outside marine protected areas, whereas the freeze the footprint approach inherently contains the premise that areas are closed unless explicitly open.

By focusing on the best available proxy data sets for the specific habitat features generally known to be more vulnerable, more diverse, more important to groundfish with an affinity for structure, and slower to recover from damage, our approach secured greater levels of overall protection than would have been possible if the objective had been to include a certain percentage of each representative habitat type. Data important for conservation design and implementation include recent bottom trawl fishing effort locations and priority seafloor habitat features, particularly the presence of deep-sea corals and sponges and hard substrates. This work represents an active implementation of adaptive management, which is a deliberate cycle of evaluation of existing regulations, planning, and implementation, and has been identified as a successful component of marine protected areas (Bennett and Dearden, 2014).

The approach in Amendment 28 further implements the "freeze the footprint" approach described in Shester and Warrenchuk (2007). Amendment 19 in 2006 closed waters deeper than 1,280 $\mathrm{m}$ but did not close areas deeper than 3,500 $\mathrm{m}$ or the vast area of the Southern California Bight shallower than 1,280 m. Amendment 28 further implemented the freeze the footprint policy by closing all areas deeper than $3,500 \mathrm{~m}$ and much of the Southern California Bight, in addition to many untrawled areas shallower than $1,280 \mathrm{~m}$. Since these are precautionary closures, certain areas could be reopened in the future if new research and data can demonstrate such action would not damage priority habitats.

The Amendment 28 regulations further shift the burden of proof on fishers to first demonstrate they will not damage priority habitat features before being permitted into a conservation area (Dayton, 1998). Prior to these closures, fishing activity could have expanded into deep, unfished waters or other new areas as the technological ability to access these areas advanced or as market conditions changed. Now, expansion into new areas may only occur if there is new scientific evidence that it will minimize harm to ecosystems. Because deep-sea environments are largely unexplored and impacts to marine habitats could be severe, global adoption of the precautionary approach by prohibiting new industrial activities in the deep-sea, as was done with implementation of the Deep-Sea Ecosystem Conservation Area off California, is essential.
Freezing the footprint of bottom trawling and protecting known sensitive habitats is a policy approach that could be readily applied to ocean areas throughout the world. In 2012, the North Pacific Fisheries Commission adopted a similar freeze the footprint approach closing more than $90 \%$ of international waters in the area under its authority to bottom trawling and other bottom contact fishing gears as an interim measure to protect vulnerable marine ecosystems ${ }^{17}$. In 2016, the European Union prohibited deep-sea bottom trawling in the NorthEast Atlantic below a depth of $800 \mathrm{~m}^{18}$. The precautionary precedent set in Amendment 28 that prohibits deep-sea bottom contact fishing could be applied to current international policy approaches to deep-sea mining, which poses an imminent threat to seafloor ecosystems which are still relatively unknown and unexplored compared to shallow-water or terrestrial ecosystems (Wedding et al., 2015).

While win-wins in marine conservation are rare, the approach outlined here for informing the management of bottom trawling and other bottom contact fishing gears demonstrates that a precautionary approach coupled with an iterative science-driven stakeholder process using geospatial analysis can provide the necessary information to achieve a win-win outcome. While there were notable exceptions for certain habitat features in certain depth zones, overall our results demonstrate the net outcome of the new regulations represents a substantial win for the conservation of deep-sea corals and sponges and other sensitive habitats across depths and bioregions off the United States West Coast (Table 2). Similarly, our results demonstrate a win for fishing opportunities coastwide and in all depths and bioregions analyzed (Table 3). The quantitative results of this analysis at multiple biogeographic and depth scales - independently validated in public statements by fishing industry representatives, Council members, and other stakeholders - demonstrate that such win-wins are achievable under the right circumstances. The conservation benefit to such win-win outcomes is that protections are more likely to be implemented, and increases the effectiveness of marine ecosystem conservation because fishers are more likely to comply with regulations that they helped to support (Viteri and Chavez, 2007; Arias et al., 2015). We conclude that the new regulations are likely to represent an enduring and positive outcome for deep-sea coral and sponge ecosystems and long-term sustainable fisheries for future generations.

\section{DATA AVAILABILITY STATEMENT}

All datasets generated by this study are included in the article and Supplementary Material. The majority of the GIS data used in our analysis was obtained directly from the NOAA Consolidated GIS Data Catalog and Online Registry for the 5-Year Review of Pacific Coast Groundfish EFH (EFH Catalog for short), either through the 'Map Services'

\footnotetext{
${ }^{17}$ https://www.un.org/depts/los/reference_files/Presentations/PPT/Segment4/ DYM.pdf

${ }^{18}$ https://www.europarl.europa.eu/news/en/press-room/20161208IPR55152/ meps-ban-deep-sea-fishing-below-800-meters-in-the-north-east-atlantic
} 
tab, located here: https://www.webapps.nwfsc.noaa.gov/data/ efh-catalog/mapservice.html or in the various 'Data' tabs organized by topic located here: https://www.webapps.nwfsc. noaa.gov/data/efh-catalog/Overview2.html. Spatial data can be downloaded either as map packages or as layer file. Postprocessing was required to access data and export it into ArcMap shapefiles for use in our analysis. Groundfish EFH spatial data including regulatory boundaries and updated substrate layers can also be accessed through the NOAA FRAM Data Warehouse, at: https://www.webapps.nwfsc.noaa.gov/data/map, where it can be downloaded in various ArcGIS file types. NOAA deep-sea coral and sponge data can be accessed at: https://deepseacoraldata. noaa.gov/. Please contact NOAA staff for assistance accessing NOAA data.

\section{AUTHOR CONTRIBUTIONS}

GS outlined the manuscript and presented at the 7 th International Deep-Sea Coral Symposium. GS, BE, BM, AB-D, and TB participated in the conservation advocacy activities. GS and $\mathrm{BE}$ led the scientific expeditions. AB-D and BM participated in, contributed toward, and provided support for the expeditions. GS, BE, BM, AB-D, and TB wrote the manuscript. BM conducted geospatial analysis and prepared map figures. BE formatted data tables and chart figures. SM supervised all writing, analysis, advocacy activities, and edited the manuscript. All authors contributed to the article and approved the submitted version.

\section{FUNDING}

The funding for Oceana's work to protect seafloor habitat off the United States West Coast was provided by the David and

\section{REFERENCES}

Althaus, F., Williams, A., Schlacher, T. A., Kloser, R. J., Green, M. A., Barker, B. A., et al. (2009). Impacts of bottom trawling on deep-coral ecosystems of seamounts are long-lasting. Mar. Ecol. Prog. Ser. 397, 279-294. doi: 10.3354/ meps08248

Arias, A., Cinner, J. E., Jones, R. E., and Pressey, R. L. (2015). Levels and drivers of fishers' compliance with marine protected areas. Ecol. Soc. 20:19. doi: 10.5751/ ES07999-200419

Atkinson, S., Libby, T., Jud, S., Pettinger, B., and Kauer, K. (2016). Updated Collaborative Package of Changes to Groundfish Essential Fish Habitat Conservation Areas and the Trawl Rockfish Conservation Area. Pacific Fishery Management Council Agenda Item F.5.c Supplemental Public Comment, Vol. 4. Portland, OR: Pacific Fishery Management Council,

Austin, W. C., Conway, K. W., Vaughn Barrie, J., and Krautter, M. (2007). "Growth and morphology of a reef-forming sponge, Aphrocallistes vastus (Hexactinellida), and implications for recovery from widespread trawl damage," in Porifera Research: Biodiversity, Innovation and Sustainability, Vol. 694, eds M. R. Custódio, G. L. ôbo-Hajdu, E. Hajdu, and G. Muricy (Rio de Janeiro: Museu Nacional),

Ball, I., and Possingham, H. (2000). Marxan (v1.8.2) - Marine Reserve Design using Spatially Explicit Annealing. Brisbane: University of Queensland, 69.

Bennett, N. J., and Dearden, P. (2014). From measuring outcomes to providing inputs: governance, management, and local development for more effective
Lucile Packard Foundation, the Angel Foundation, Pacific Life Foundation, the Oak Foundation, the Marisla Foundation, and the Robertson Foundation.

\section{ACKNOWLEDGMENTS}

We thank J. Warrenchuk for reviewing the manuscript and J. Karnik for copy editing the manuscript. We also thank D. Rosen and the team of Marine Applied Research and Education; M. Gorny; B. Pedro and the crew of the R/V Miss Linda; and the crew of the R/V Derek M. Baylis for their contribution to the Oceana expeditions. We also thank G. Hanshew, F. Lockhart, and the team at the National Marine Fisheries Service West Coast Region for their work finalizing the implementing regulations. We also thank T. Hourigan, E. Clarke, H. Coleman, and P. Etnoyer of the NOAA Deep Sea Coral Program for providing advice and data. We also thank the members and staff of the Pacific Fishery Management Council for their hard work, thoughtful analysis, and public process. We also thank A. Treece, P. Shively, T. Rudolph, L. Morgan, M. Mackey, G. Helms, C. Ridings, A. Weinstein, and many other colleagues who contributed to the outcome described in this work. We also thank J. Ayers for the original vision and inspiration for this work. We also thank A. Cousteau for her advice and wisdom. We also thank the many fishers who participated in the development of Amendment 28 and supported the final outcome.

\section{SUPPLEMENTARY MATERIAL}

The Supplementary Material for this article can be found online at: https://www.frontiersin.org/articles/10.3389/fmars. 2020.525619/full\#supplementary-material

marine protected areas. Mar. Policy 50, 96-110. doi: 10.1016/j.marpol.2014.05. 005

Clark, M. R., Bowden, D. A., Rowden, A. A., and Stewart, R. (2019). Little evidence of benthic community resilience to bottom trawling on seamounts after 15 years. Front. Mar. Sci. 6:63. doi: 10.3389/fmars.2019.00063

Crowder, L., and Norse, E. (2008). Essential ecological insights for marine ecosystem-based management and marine spatial planning. Mar. Policy 32, 772-778. doi: 10.1016/j.marpol.2008.03.012

Dayton, P. K. (1998). Reversal of the burden of proof in fisheries management. Science 279, 821-822. doi: 10.1126/science.279.5352.821

de Beukelaer, S., Grimmer, K. F., Brown, J. A., and King, C. (2016). "Using GIS tools to develop a collaborative essential fish habitat proposal," in Ocean Solutions, Earth Solutions, ed. D. J. Wright (Redlands, CA: Esri Press), 201-220. doi: $10.17128 / 9781589484603$

Department of Fisheries and Oceans Canada (DFO) (2019). Pacific Region Integrated Fisheries Management Plan: Groundfish. Effective February 21, 2019, Version 1.1. 185. Available online at: http://www.pac.dfo-mpo.gc.ca/fm-gp/ mplans/ground-fond-ifmp-pgip-sm-eng.pdf (accessed January 5, 2021).

Drinkwater, K. (2004). Summary Report: Review on Evaluation of Fishing Activities That May Adversely Affect Essential Fish Habitat (EFH) in Alaska. Bergen: Center for Independent Experts.

Enticknap, B., Shester, G., Gorny, M., and Kelly, M. (2013). Important Ecological Areas Seafloor Habitat Expedition off the Southern Oregon Coast. Oceana Report. Available online at: https://oceana.org/sites/default/files/reports/Oceana_S. OregonIEA.ExpeditionReport_Final.pdf (accessed January 5, 2021). 
Foley, M. M., Halpern, B. S., Micheli, F., Armsby, M. H., Caldwell, M. R., Crain, C. M., et al. (2010). Guiding ecological principles for marine spatial planning. Mar. Policy 34, 955-966. doi: 10.1016/j.marpol.2010.02.001

Geange, S. W., Leathwick, J., Linwood, M., Curtis, H., Duffy, C., Funnell, G., et al. (2017). Integrating conservation and economic objectives in MPA network planning: a case study from New Zealand. Biol. Conserv. 210, 136-144. doi: 10.1016/j.biocon.2017.04.011

Girard, F., Shea, K., and Fisher, C. R. (2018). Projecting the recovery of a long-lived deep-sea coral species after the deepwater horizon oil spill using state-structured models. J. Appl. Ecol. 55, 1812-1822. doi: 10.1111/1365-2664. 13141

Gleason, M., McCreary, S., Miller-Henson, M., Ugoretz, J., Fox, E., Merrifielda, M., et al. (2010). Science-based and stakeholder-driven marine protected area network planning: a successful case study from north central California. Ocean Coast. Manag. 53, 52-68. doi: 10.1016/j.ocecoaman.2009. 12.001

Guinotte, J. M., and Davies, A. J. (2014). Predicted deep-sea coral habitat suitability for the U.S. West Coast. PLoS One 9:e93918. doi: 10.1371/journal.pone.0093918

Heifetz, J. (2002). Coral in Alaska: distribution, abundance, and species associations. Hydrobiologia 471, 19-28. doi: 10.1023/A:1016528631593

Hourigan, T. F. (2009). Managing fishery impacts on deep-water coral ecosystems of the USA: emerging best practices. Mar. Ecol. Prog. Ser. 397, 333-340. doi: 10.3354/meps08278

Howe, C., Corbera, E., Vira, B., Brockington, D., and Adams, W. (2018). Distinct positions underpin ecosystem services for poverty alleviation. Oryx 54, 375382. doi: 10.1017/S0030605318000261

Husebo, A., Nottestad, L., Fossa, J., Furevik, D., and Jorgensen, S. (2002). Distribution and abundance of fish in deep-sea coral habitats. Hydrobiologia 471, 91-99. doi: 10.1023/A:1016549203368

Johnson, H. P. (2008). Washington Sea Grant Progress Report Project R/NP-6 for the period 2/1/2007 - 4/30/12 "Glass Sponge Reef Habitat in the Pacific Northwest". Available online at: https://wsg.washington.edu/research/glasssponge-reef-habitat-in-the-pacific-northwest/ (accessed January 5, 2021).

Koslow, J. A., Boehlert, G. W., Gordon, J. D. M., Haedrich, R. L., Lorance, P., and Parin, N. (2000). Continental slope and deep-sea fisheries: implications for a fragile ecosystem. ICES J. Mar. Sci. 57, 548-557. doi: 10.1006/jmsc. 2000. 0722

Krieger, K. J., and Wing, B. L. (2002). Megafauna associations with deepwater corals (Primnoa spp.) in the Gulf of Alaska. Hydrobiologia 471, 83-90. doi: 10.1023/A: 1016597119297

Leathwick, J., Moilanen, A., Francis, M., and Elith, J. (2008). Novel methods for the design and evaluation of marine protected areas in offshore waters. Conserv. Lett. 1, 91-102. doi: 10.1111/j.1755-263X.2008.00012.x

Lohn, D. R. (2006). (NMFS Northwest Regional Administrator). Letter to Mr. Donald Hansen, Chair, Pacific Fishery Management Council. March 8, 2006. Suppl. Informational Report 7. Portland, OR: Pacific Fishery Management Council.

McConnaughey, R. A., Hiddink, J. G., Jennings, S., Pitcher, C. R., Kaiser, M. J., Suuronen, P., et al. (2020). Choosing best practices for managing impacts of trawl fishing on seabed habitats and biota. Fish Fish. 21, 319-337. doi: 10.1111/ faf. 12431

McShane, T. O., Hirsch, P. D., TranChi, T., Songorwa, A. N., Kinzig, A., Monteferri, B., et al. (2011). Hard choices: making trade-offs between biodiversity conservation and human well-being. Biol. Conserv. 144, 966-972. doi: 10.1016/ j.biocon.2010.04.038

Merrifield, M. S., McClintock, W., Burt, C., Fox, E., Serpa, P., Steinback, C., et al. (2013). MarineMap: a web-based platform for collaborative marine protected area planning. Ocean Coast. Manag. 74, 67-76. doi: 10.1016/j.ocecoaman.2012. 06.011

National Research Council (NRC) (2002). Effects of Trawling and Dredging on Seafloor Habitat. Washington, DC: National Research Council.

NMFS (2005). Final Groundfish Essential Fish Habitat (EFH) Environmental Impact Statement. Available online at: https://www.fisheries.noaa.gov/west-coast/lawsand-policies/groundfish-actions-nepa-documents (accessed January 5, 2021).

NMFS (2013). Groundfish Essential Fish Habitat Synthesis Report. Agenda Item D.6.b NMFS Synthesis Report. Portland, OR: Pacific Fishery Management Council.
NMFS (2014). Rockfish conservation area boundaries for vessels using bottom trawl gear. Final Rule 74:21639.

NMFS (2019a). Changes to Pacific Coast Groundfish Essential Fish Habitat Conservation Areas and Boundaries of the Trawl Gear Rockfish Conservation Area Final Environmental Impact Statement, Magnuson-Stevens Act Analysis, Regulatory Impact Review, and Regulatory Flexibility Analysis. Washington, D.C: National Oceanic and Atmospheric Administration.

NMFS (2019b). Fishery management plan amendment 28. Final Rule 84, 6396663992.

NMFS (2020). Vessel monitoring system final rule. Fed. Regist. 85, 81085-81336.

NOAA and Oregon State University (OSU) (2012). Five-Year Review of Pacific Coast Groundfish EFH Consolidated EFH Geographic Information Data Catalog. Available online at: https://www.webapps.nwfsc.noaa.gov/data/efhcatalog/ (accessed January 5, 2021).

NOAA Map Service (2018). Aggregated Presence of Deep-Sea Corals, Sponge and Pennatulids off the U.S. Pacific Coast. Available online at: https://www.webapps. nwfsc.noaa.gov/data/map (accessed January 5, 2021).

NOAA National Database for Deep-Sea Corals and Sponges (2017). Database version December 14, 2017. NOAA Deep Sea Coral Research \& Technology Program. Available online at: https://deepseacoraldata.noaa.gov/ (accessed January 5, 2021).

NOAA (2015). Distribution and intensity of commercial bottom trawl fishing effort off the U.S. Pacific Coast (1 Jan 2002-2011 Jun 2006). Available online at: https: //www.webapps.nwfsc.noaa.gov/data/efh-catalog/ (accessed January 5, 2021).

North Pacific Fishery Management Council (NPFMC) (2009). Fishery Management Plan for Fish Resources of the Arctic Management Area. Anchorage, Alaska. Available online at: https://www.npfmc.org/wp-content/PDFdocuments/fmp/ Arctic/ArcticFMP.pdf (accessed January 5, 2021).

North Pacific Fishery Management Council (NPFMC) (2018). Fishery Management Plan for Groundfish of the Bering Sea and Aleutian Islands Management Area. Available online at: https://www.npfmc.org/wp-content/PDFdocuments/fmp/ BSAI/BSAIfmp.pdf (accessed January 5, 2021).

North Pacific Fishery Management Council (NPFMC) (2019). Fishery Management Plan for Groundfish of the Gulf of Alaska. Anchorage, Alaska. August 2019. Available online at: https://www.npfmc.org/wp-content/PDFdocuments/fmp/ GOA/GOAfmp.pdf (accessed January 5, 2021).

Northwest Fisheries Science Center (NWFSC) (2011). Groundfish Probability. Available online at: https://www.webapps.nwfsc.noaa.gov/data/efh-catalog/ mapservice.html (accessed January 5, 2021).

Oceana, Natural Resources Defense Council, and Ocean Conservancy (2013). Proposal to the Pacific Fishery Management Council to Modify Groundfish Essential Fish Habitat Designation, Conservation and Enforcement. Comprehensive Conservation Proposal. Available online at: https://s3.amazonaws.com/s3.oceana.org/images/Final.Oceana.NRDC.OC.7. 31.13.EFHProposal-2.pdf (accessed January 5, 2021).

Oregon State University, Active Tectonic and Seafloor Mapping Lab (OSU) (2018). Surficial Geologic Habitat Induration, Version 4.0. Available online at: https://www.webapps.nwfsc.noaa.gov/server7/rest/services/FRAM/USWest Coast_SeafloorInduration_v4_0/MapServer (accessed January 5, 2021).

Oregon State University, Active Tectonic and Seafloor Mapping Lab (OSU) (2004). U.S. West Coast Geological Seafloor Habitat Characterization for Essential Fish Habitat (EFH). Portland, OR: Pacific States Marine Fisheries Commission. Available online at: http://marinehabitat.psmfc.org/gis-data.html (accessed January 5, 2021).

Pacific Fishery Management Council (PFMC) (2019). Pacific Coast Groundfish Fishery Management Plan. Portland, OR: Pacific Fishery Management Council (PFMC).

Pikitch, E., Santora, C., Babcock, E. A., Bakun, A., Bonfil, R., Conover, D. O., et al. (2004). Ecosystem-based fishery management. Science 305, 346-347. doi: $10.1126 /$ science. 1098222

Powell, A., Clarke, M. E., Fruh, E., Chaytor, J. D., Reiswig, H. M., and Whitmire, C. E. (2018). Characterization of the sponge grounds of grays canyon, Washington, USA. Deep-Sea Res. Part II 150, 146-155. doi: 10.1016/j.dsr2.2018. 01.004

Roark, E. B., Guilderson, T. P., Dunbar, R. B., Fallon, S. J., and Mucciarone, D. A. (2009). Extreme longevity in proteinaceous deep-sea corals. PNAS 106, 5204-5208. doi: 10.1073/pnas.0810875106 
Sala, E., Aburto-Oropeza, O., Paredes, G., Parra, I., Barrera, J. C., and Dayton, P. K. (2002). A general model for designing networks of marine reserves 2002. Science 298, 1991-1993. doi: 10.1126/science.107 5284

Salgado, E. J., Nehasil, S. E., and Etnoyer, P. J. (2018). Distribution of deep-water corals, sponges, and demersal fisheries landings in Southern California, USA: implications for conservation priorities. PeerJ 6:e5697. doi: 10.7717/peerj.5697

Sharp, B. R., and Watters, G. M. (2011). Marine Protected Area Planning by New Zealand and the United States in the Ross Sea Region. CCAMLR WSMPA-11/25. 39. Available online at: http://www.ccamlr.org/en/ws-mpa-11/25 (accessed January 5, 2021).

Shester, G., and Warrenchuk, J. (2007). "U.S. pacific coast experiences in achieving deep-sea coral conservation and marine habitat protection," in Conservation and Adaptive Management of Seamount and Deep-Sea Coral Ecosystems, eds R. Y. George and S. Cairns (Coral Gables, FLA: University of Miami), 169-184.

Shester, G., Enticknap, B., Kincaid, E., Lauermann, A., and Rosen, D. (2017). Exploring the Living Seafloor: Southern California Expedition. Oceana Report. September 2017. Available online at: https://usa.oceana.org/sites/default/files/ exploring_the_living_seafloor_report_med_res_spreads.pdf (accessed January 5, 2021).

Tong, R., Purser, A., Unnithan, V., and Guinan, J. (2012). Multivariate statistical analysis of distribution of deepwater gorgonian corals in relation to seabed topography on the Norwegian margin. PLoS One 7:e43534. doi: 10.1371/ journal.pone.0043534

Viteri, C., and Chavez, C. (2007). Legitimacy, local participation, and compliance in the Galapagos Marine Reserve. Ocean Coast. Manag. 50, 253-274. doi: 10. 1016/j.ocecoaman.2006.05.002

Wallace, S., Turris, B., Driscoll, J., Bodtker, K., Mose, B., and Munro, G. (2015). Canada's pacific groundfish trawl habitat agreement: a global first in an ecosystem approach to bottom trawl impacts. Mar. Policy 60, 240-248. doi: 10.1016/j.marpol.2015.06.028

Watanabe, S., Metaxas, A., Sameoto, J., and Lawton, P. (2009). Patterns in abundance and size of two deep-water gorgonian octocorals, in relation to depth and substrate features off Nova Scotia. Deep Sea Res. Part I 56, 2235-2248.

Watling, L., and Norse, E. (1998). Disturbance of the seabed by mobile fishing gear: a comparison to forest clearcutting. Conserv. Biol. 12, 1180-1197. doi: 10.1046/j.1523-1739.1998.0120061180.x

Wedding, L. M., Reiter, S. M., Smith, C. R., Gjerde, K. M., Kittinger, J. N., Friedlander, A. M., et al. (2015). OCEANS managing mining of the deep seabed. Science 349, 144-145. doi: 10.1126/science.aac6647

Williams, A., Schlacher, T. A., Rowden, A. A., Althaus, F., Clark, M. R., Bowden, D. A., et al. (2010). Seamount megabenthic assemblages fail to recover from trawling impacts. Mar. Ecol. 31, 183-199.

Xiao, H., Dee, L. E., Chadès, I., Peyrard, N., Sabbadin, R., Stringer, M., et al. (2018). Win-wins for biodiversity and ecosystem service conservation depend on the trophic levels of the species providing services. J. Appl. Ecol. 55, 2160-2170. doi: $10.1111 / 1365-2664.13192$

Conflict of Interest: The authors declare that the research was conducted in the absence of any commercial or financial relationships that could be construed as a potential conflict of interest.

Copyright (C) 2021 Shester, Enticknap, Mecum, Blacow-Draeger, Brock and Murray. This is an open-access article distributed under the terms of the Creative Commons Attribution License (CC BY). The use, distribution or reproduction in other forums is permitted, provided the original author(s) and the copyright owner(s) are credited and that the original publication in this journal is cited, in accordance with accepted academic practice. No use, distribution or reproduction is permitted which does not comply with these terms. 